\title{
Once More into the Breach: Promissory Estoppel and Traditional Damage Doctrine
}

When, in the absence of traditional contract formalities, a promise is enforced because the promisee has acted in reliance ${ }^{1}$ upon it, both courts and commentators have disagreed over the proper measure of damages. Early in the debate, two positions could be discerned. Advocates of the one favored enforcing the promise according to its terms and awarding the promisee full contractual damages. ${ }^{2}$ This measure of recovery has come to be called the expectation interest ${ }^{3}$ and is an attempt to put the promisee in the same position as he would have been had the promise been fulfilled. ${ }^{4}$ Advocates of the other position would have limited the promisee to recovery of those tangible expenditures made in reliance on the promise. ${ }^{5}$ This measure of recovery has become known as the reliance interest. It attempts to put the promisee in the same position he would have been in had the promise and the subsequent reliance never taken place. ${ }^{6}$ More recently, perhaps in rec-

1 Throughout this comment the phrases "enforcement of a promise because of reliance," "action-in-reliance," and "promissory estoppel" will be used synonymously. These expressions refer to putatively unbargained for, detrimental reliance in the sense articulated in RESTATEMENT OF ContRAGTS \$ 90 (1932): "A promise which the promisor should reasonably expect to induce action or forbearance of a definite and substantial character on the part of the promisee and which does induce such action or forbearance is binding if injustice can be avoided only by enforcement of the promise." They do not refer to action in reliance which constitutes part performance of the promisee's consideration. E.g., id. § 45 .

2 This was the position taken by Professor Williston in the American Law Institute's deliberations over the forebear of $\S$ 90, 4 ALI Procendings App. 97-106 (1925); Comment, The Measure of Damages for Breach of a Contract Created by Action in Reliance, 48 YALE L.J. 1036 (1939); Note, Promissory Estoppel-Measure of Damages, 13 VAND. L. REv. 705 (1960). See, e.g., Northwestern Eng'r Co. v. Ellerman, 71 S.D. 236, 23 N.W.2d 273 (1946); Chrysler Corp. v. Quimby, 51 Del. 264, 144 A.2d 123 (1958).

3 The categories of recovery are most comprehensively examined in Fuller \& Perdue, The Reliance Interest in Contract Damages (pts. 1-2), 46 YALE L.J. 52, 373, especially $52-57$ (1936) [hereinafter cited as Fuller \& Perdue].

4 Id. at 54 .

5 Gardner, An Inquiry into the Principles of the Law of Contracts, 46 HARv. L. Rev. 1, 22-23 (1932); Seavey, Reliance on Gratuitous Promises or Other Conduct, 64 HARv L. Rev. 913, 926 (1951); Shattuck, Gratuitous Promises-A New Writ?, 35 Mrch. L. ReV 908, 942-3 (1937) [hereinafter cited as Shattuck]; 65 Mich. L. REv. 351, 356 (1966). E.g., Goodman v. Dicker, I69 F.2d 684 (D.C. Cir. 1948) (but see text at notes 141.6 infra); Wheeler v. White, 398 S.W.2d 93 (Sup. Ct. Tex. 1965) (but see text at notes 158-9 infra).

6 Fuller \& Perdue at 54. 
ognition of the fact that action-in-reliance might constitute the basis for promissory liability in increasingly disparate contexts, ${ }^{7}$ some commentators have advocated the ad hoc administration of remedies in an attempt to work "substantial justice" in any particular situation..$^{8}$ It may indeed be impossible to formulate a comprehensive rule of damages for all circumstances in which action-in-reliance, or promissory estoppel, is the basis of recovery. Nevertheless, it is submitted that within the wide range of contexts in which promissory estoppel may operate, there exist reasonably discrete subgroups with respect to which one may make meaningful generalizations regarding the proper measure of damages.

This comment concerns one of these subgroups: the business or exchange transaction where, for one reason or another, a promise is enforced because of action-in-reliance rather than because it is embodied in an agreement complying with the formal requirements of the doctrine of consideration. While the most frequently reported cases involve firm offers ${ }^{9}$ and instances of reliance during precontractual negotiations, ${ }^{10}$ these do not exhaust the possibilities. ${ }^{11}$

Part I of this comment reviews the extension of action-in-reliance as a basis for liability from cases involving gratuitous promises ${ }^{12}$ to cases arising out of commercial transactions. Part II explores the choice-ofawards problem posed by commercial reliance liability in terms of

7 See text at notes 15-23 infra.

8 1A A. Conbin, Contracts $\S 205$ (1964 ed.) [hereinafter cited as CoRbin]; Fuller \& Perdue at 405-6; Kessler \& Fine, Culpa in Contrahendo: Bargaining in Good Faith and Freedom of Contract: A Comparative Study, 77 HARv. L. REv. 401,424 (1964). Cf. 65 Mrch. L. Rev. 351, 356 (1966). This approach was apparently adopted in Hoffman v. Red Owl Stores, Inc., 26 Wis. 2d 683, 700-2, 133 N.W.2d 267, 276-7 (1965). But see text at notes 135-7 infra. It has also been adopted by the proposed Restatement (SECOND) OF CoNTRACTS $\S \S 89 \mathrm{~B}(2)$ at 135,90 at 165 (Tent. Draft No. 2, 1965), set out in notes 107.8 infra. See text at notes 106-19 infra.

9 E.g., N. Litterio \& Co. v. Glassman Constr. Co., 319 F.2d 736 (D.C. Cir. 1963); James Baird Co. v. Gimbel Bros., Inc., 64 F.2d 344 (2d Cir. 1933); Drennan v. Star Paving Co., 51 Cal. 2d 409, 333 P.2d 757 (1958).

10 E.g., Chrysler Corp. v. Quimby, 51 Del. 264, I44 A.2d 123 (1958); Hoffman v. Red Owl Stores, Inc., 26 Wis. 2d 683, 133 N.W.2d 267 (1965); cf. Goodman v. Dicker, 169 F.2d 684 (D.C. Cir. 1948).

11 E.g., Peoples Nat'l Bank v. Linebarger Constr. Co., 219 Ark. 11, 240 S.W.2d 12 (1951) (representation of amounts coming due under a contract to assignee thereof); Anthony v. Hilo Elec. Light Co., 442 P.2d 64 (Hawaii 1968) (promise to reimburse plaintiff from sums to be paid defendant by third party); Central Heat, Inc. v. Daily Olympian, Inc., 74 Wash. 2d 126, 443 P.2d 544 (1968) (reliance on promise to take steam during season). See also Hilltop Properties v. State, 233 Cal. App. 2d 349, 43 Cal. Rptr. 605 (1965) (promise by state to purchase land which it would eventually have to condemn).

12 The most prominent situations involved charitable gifts of land, gratuitous agencies and bailments, and antenuptial agreements. See generally Boyer, Promissory Estoppel: Principle from Precedent, 50 MrCH. L. Rev. 639, 873 (1952); Henderson, Promissory Estoppel and Traditional Contract Doctrine, 78 YALE L.J. 343, 350-1 (1969) [hereinafter cited as Henderson]; Fuller \& Perdue at 402-4; Shattuck at 915-35. 
underlying jurisprudential and economic considerations; it concludes that with a few exceptions the damages awarded should be determined by those rules which prescribe damages for breach of contract. Part III examines some recent cases in light of the theoretical conclusions drawn in Part II. In an effort to explain some of the departures from theoretical consistency, it will be suggested that there are instances in which promissory estoppel is invoked not as a substantive theory of recovery, but rather as a strategy of damage manipulation.

The incorporation of the narrow Holmes-Williston ${ }^{13}$ concept of consideration into the Restatement of Contracts required the addition of a provision that would accommodate the numerous cases in which promises of a generally gratuitous nature had been enforced despite the absence of consideration as defined by the Restatement. ${ }^{14}$ That provision was section 90 , which has perhaps been more cited and discussed than any other provision. Two of the section's peculiarities are of immediate concern.

The first involves the abstract language employed by the Restatement's drafters. Although they apparently felt that the section was to cover only gratuitous promises, ${ }^{15}$ it was cast in language which does not limit its applicability to non-commercial promises. ${ }^{16}$ And although some subsequent commentators assumed ${ }^{17}$ and some courts held such a lim-

13 Restatement of Contracts \& 75 (1932):

(1) Consideration for a promise is

(a) an act other than a promise, or

(b) a forbearance, or

(c) the creation, modification or destruction of a legal relation, or

(d) a return promise, bargained for and given in exchange for the promise.

" $[I] \mathrm{t}$ is the essence of a consideration, that, by the terms of the agreement, it is given and accepted as the motive or inducement of the promise. Conversely, the promise must be made and accepted as the conventional motive or inducement for furnishing the consideration." O.W. Holmes, The Common LAW 293 (1881); Wisconsin \& Michigan R.R. v. Powers, 191 U.S. 379, 386 (1903) (Holmes, J.); Henderson at 345.

14 Professor Gilmore relates that after the drafters of the Restatement had settled on a definition of consideration substantially similar to the eventual \& 75, Professor Corbin felt compelled to express his opinion that the definition adopted was entirely too narrow. After some research, and by way of making his point as persuasively as possible, he confronted the drafters with a plethora of cases enforcing promises which would have been unenforceable within the definition proposed for the Restatement. And although Professor Corbin would have preferred expanding the definition contained in $\S 75$, a compromise resulted in the formulation of the present $\$ 90$.

15 See note 12 supra and authorities cited therein. The illustrations accompanying $\$ 90$ in the RESTATEMENT OF CONTRACTS (Official Draft, 1932) all involve gratuitous promises.

16 See note 1 supra.

17 For example, Fuller and Perdue's discussion of this section seems to proceed on the 
itation to exist, ${ }^{18}$ the scope of section 90 has gradually broadened..$^{19}$ Thus, in such areas as firm offers, ${ }^{20}$ the granting of franchises, ${ }^{21}$ and precontractual negotiations in general, promissory estoppel has become an accepted basis for liability. The increasing scope of promissory estoppel may have been in some sense inevitable: promissory estoppel may be but an additional symptom of the progressive expansion of civil obligation during the twentieth century. ${ }^{22}$ The sweeping language of section 90 , however, very likely hastened the expansion of reliance liability. ${ }^{23}$

The second peculiarity surrounds the question of the proper award for promises enforced because of reliance. Despite the initially gratuitous nature of promises intended to be enforced under section 90 , it is clear from both the systematics of the Restatement ${ }^{24}$ and its legislative history ${ }^{25}$ that such promises were intended to be enforced according to their terms: a promisee entitled to recover under section 90 would have been entitled to whatever remedy the Restatement pre-

assumption that $\S 90$ promises will be gratuitous. Fuller \& Perdue at 63-65, 401-6. See also Boyer, supra note 12, at 640-4; Shattuck at 908-14.

18 E.g., James Baird Co. v. Gimbel Bros., Inc., 64 F.2d 344 (2d Cir. 1933); Comfort v. McCorkle, 149 Misc. 826, 268 N.X.S. 192 (Sup. Ct. 1933).

19 See generally Henderson at 343-4, 350 et seq.

20 E.g., Drennan v. Star Paving, 51 Cal. 2d 409, 333 P.2d 757 (1958); Northwestern Eng'r Co. v. Ellerman, 69 S.D. 397, 10 N.W.2d 879 (1943); cf. Robert Gordon, Inc. v. Ingersoll-Rand Co., 117 F.2d 654 (7th Cir. 1941).

21 See authorities cited note 10 supra.

22 See text at notes 85-91 infra; cf. Ellinghaus, In Defense of Unconscionability, 78 YaLE L.J. 757, 765 (1969); Comment, Lost Profits As Contract Damages: Problems Of Proof And Limitations On Recovery, 65 YALE L.J. 992, 1000 (1965) [hereinafter cited as Lost Profits As Contract Damages].

23 Cf. E. Levi, AN Introduction to Legar. REAsoning 8-9 (1948). With the broad formulation of the section, some commentators directed their energies to a constructional analysis of its terms. E.g., Boyer, Promissory Estoppel: Requirements and Limitations of the Doctrine, 98 U. PA. L. REv. 459 (1950). The language of $\$ 90$ has been similarly parsed and examined by some courts. E.g., N. Litterio \& Co. v. Glassman Constr. Co., 319 F.2d 736, 739 (D.C. Cir. 1963); Hoffman v. Red OwI Stores, Inc., 26 Wis. 2d 683, 698, 133 N.W.2d 267,275 (1967). In fact, most of the recent cases enforcing promise because of action-inreliance do so in terms of $\S 90$.

24 The Restatement provides no particular remedy for breach of a promise enforced under $\$ 90$; damages are presumably to be ascertained by the same rules provided by the Restatement for breach of contract, which do not include the reimbursement of reliance

losses. Fuller \& Perdue at 401-6. But see Kessler \& Fine, supra note 8, at 424. See also the alteration proposed for the RESTATEMENT (SECOND) OF CoNTRACTS, notes 107-8, and text at notes 106-19 infra.

25 An often-quoted dialogue from the American Law Institute's deliberations on the Restatement indicate that Professor Williston clearly adhered to this view. In a discussion with Mr. Coudert, among others, Williston asserted that if Uncle were to promise Johnny $\$ 1,000$ with which to purchase a car, in reliance upon which Johnny bought a $\$ 500$ car, Uncle was obligated to Johnny according to the terms of the promise, i.e., for $\$ 1,000$. 4 ALI Proceedincs App. 97-106 (1926). 
scribed for breach of contract. This result, however, stuck in the throats of numerous commentators. ${ }^{26}$ It was difficult to brook the notion that if Johnny bought a $\$ 500$ car in reliance on Uncle's promise of $\$ 1,000$ with which to make the purchase, Uncle owed Johnny $\$ 1,000 .{ }^{27}$ In these early discussions, then, Williston's view, which seemed to sacrifice common sense to theoretical consistency, was far less satisfactory than the position of commentators who favored compensation of the promisee to the extent of his reliance, usually measured by his tangible out-of-pocket expenditures. ${ }^{28}$

But the propriety of the results dictated by a rule limiting reimbursement to out-of-pocket expenditures declined as the use of promissory estoppel expanded into commercial settings. ${ }^{29}$ Since a businessman who sought damages for breach of contract was entitled to recover the value of the expectation interest, which included not only losses sustained but also gains prevented by the breach, ${ }^{30}$ it was difficult to see why a businessman seeking to enforce a promise on which he had relied should be limited to recovery of the reliance interest, ${ }^{31}$ which did not normally include gains prevented. ${ }^{32}$ Nevertheless, the feeling persisted that, even if promissory estoppel was a proper ground for the enforcement of commercial promises, the resulting obligations were not truly contractual, and the resulting damages should accordingly be less than normal contractual awards. ${ }^{33}$ The confusion was enhanced by the implicit assumption that a single measure of damages should be applied to all promises enforced because of reliance, whether they arose in com-

26 Boyer, supra note 23, at 490-1, 496-7; Fuller \& Perdue at 63-65, 401-6, 420; Shattuck at $941-5$.

27 See note 25 supra.

28 See authorities cited note 26 supra.

29 It is interesting to note that views as to the proper measure of damages seem to vary with the types of cases with which an author is primarily concerned. For instance, the author of Comment, Measure of Damages For Breach of a Contract Created by Action In Reliance, 48 YALE L.J. 1036 (1939), recognized the propriety of reliance enforcement in business contexts, id. at 1043 et seq., and came to the conclusion that all promises enforced because of reliance should be enforced according to their terms. Id. at 1051-2. On the other hand, Boyer, sucpra note 23, who examined numerous non-commercial and commercial cases, could not seem to decide whether full enforcement or partial enforcement was appropriate. $I d$. at 488-97. Neither, however, attempted to examine the commercial and non-commercial cases separately to see if general observations could be made with respect to each group.

305 Corbin § 992; Fuller \& Perdue at 55. See also Lost Profits As Contract Damages, supra note 22.

31 Comment, stupra note 29, at 1052.

32 Fuller and Perdue never quite inform us whether or when they feel the reliance interest should cover gains prevented. Fuller \& Perdue at 55. See text and notes at notes $52-53$ infra; cf. Lost Profits As Contract Damages at 1004.

3:s 65 МICH. L. REv. 351, 355-6 (1966). 
mercial or non-commercial contexts. And the product of this confusion was the emergence of a third view which advocated a "flexible" approach to the problem. ${ }^{34}$ Under this rubric the commentators exhorted the courts to shape damage awards in the interest of finding a unique and just solution in each instance. A few potentially relevant guidelines were advanced to aid in this endeavor. ${ }^{35}$

Although doctrinally weak, such a flexible approach possesses the virtue of fostering explicit recognition of otherwise unacknowledged factors which probably influence the award of damages for normal breach of contract. ${ }^{36}$ Moreover, the power to tailor awards to fit particular situations favors the grant of at least a partial remedy to an aggrieved party: a court which feels compelled to award full contractual damages if a promise is enforced because of reliance might prefer to award no damages at all. Indeed, one of the principal arguments on behalf of the flexible approach is that prescription of too strict a measure of damages might unduly curtail the use of promissory estoppel. ${ }^{37}$

Whatever the merits of this flexible approach, its existence might suggest, misleadingly, that meaningful generalizations about the proper measure of damages for a promise enforced because of reliance are not

34 Authorities cited note 8 supra. See also Seavey, supra note 5, at 926.

35 Factors usually suggested in this regard are: (1) whether the promise induced the action-in-reliance; (2) whether the reliance was substantial; (3) whether the action-inreliance was desired by the promisor regardless of whether he bargained for it; (4) whether the reliance was foreseeable; (5) whether the promised performance was costly; (6) what ratio the value of the action-in-reliance bears to the promised performance. 1A CoRBIN § 205; cf. 65 MICH. L. REv. 351, 356 (1966). Inasmuch as factors 1, 2, and 4 are considered by the court in determining whether to apply $\$ 90$, they presumably contribute nothing additional in determining the particular remedy. Since factor 3 is in part an inquiry into the extent to which the parties were motivated by a desire for mutual benefit through exchange, see text at note 54 infra, it is arguable that the action-in-reliance, although not the "conventional inducement for the promise," will in some sense have been "desired" by the promisor. See text and notes at notes 95-100 infra; see, e.g., Drennan v. Star Paving Co., 51 Cal. 2d 409, 333 P.2d 757 (1958); Chrysler Corp. v. Quimby, 51 Del. 264, 144 A.2d 123 (1958); Wheeler v. White, 398 S.W.2d 93 (Sup. Ct. Tex. 1965). Contra, James Baird Co. v. Gimbel Bros., Inc., 64 F.2d 344 (2d Cir. 1933). Factor 6 arguably brings into play traditional concern for the possibility of rendering a disproportionately large verdict. See text and notes at notes $65-69$ infra.

36 The most prominent such consideration is again the desire to avoid rendering a disproportionate verdict, a problem dealt with in contracts cases by requiring plaintiff to prove his losses to have been foreseeable, certain, and in fact caused by defendant's breach. See generally Lost Profits As Contract Damages passim. Under factor 6, supra note 35 , this problem would be given explicit recognition in reliance-enforcement situations. The reasonableness of a party's conduct is often accorded explicit recognition by promissory estoppel, Hoffman v. Red Owl Stores, Inc., 26 Wis. 2d 683, 692, 133 N.W.2d 267, 272 (1965) (approved instruction required exercise of ordinary care), but this problem has also been handled explicitly by the UNIForm CoMmercial CODE § 1-102(3); cf. \$ 1-201(19), 1-203 (good faith).

37 Boyer, supra note 23, at 491; 65 Mrch. L. REv. 351, 353, 358 (1966). 
possible. Recognizing that actions for breach of contract present a stronger claim for damages measured by the expectation interest when they arise from commercial rather than non-commercial contexts, ${ }^{38}$ Part II of this comment adduces reasons for drawing a similar distinction with respect to promises enforced because of reliance. The suggested analysis would enable the commercial promisee to recover full contractual damages whether the theory of recovery were action-inreliance or breach of contract, while limiting Williston's Johnny to recovery of that amount actually spent purchasing a car. ${ }^{39}$

\section{II}

Some commentators have argued that awarding full contract damages for breach of a promise enforced because of reliance is inappropriate simply because there is no consideration, and the result is to obligate the promisor to pay substantial damages when he did not have the advantage of a mutually binding agreement. ${ }^{40}$ Early authorities probably articulated this objection on the assumption that reliance enforcement would be limited to gratuitous promises, ${ }^{41}$ but the argument has endured even where the promise arose in a commercial context. ${ }^{42}$ This argument is largely terminological, and provides an inadequate solution to the problem at hand. Although the doctrine of consideration presently plays a central role in the Anglo-American law of civil obligation, ${ }^{43}$ there may be and have been alternative jurisprudential devices which fulfill the same function as consideration.44 And whatever the meaning of the requirement of "mutuality of obligation," it does not mean that a contract enforced on behalf of one party would necessarily have been enforced on behalf of the other. ${ }^{45}$ For example, the bargain

38 Fuller \& Perdue at $65-66$.

39 See the dialogue described in note 25 supra.

40 Shattuck at 943-4; 65 Mick. L. REv. 351, 355-6 (1966). Gardner seemed to proceed on the converse assumption, namely that the conduct was in reality tortious. Gardner, supra note 5, at 22-23; accord, Seavey, supra note 5, at 926.

41 See text at notes 15-18 supra. Both Gardner and Shattuck seemed to have assumed such a limitation. Gardner, supra note 5, at 23; Shattuck at 941-5.

4265 MICH. L. REv. 351, 353 (1966).

43 See generally Fuller, Consideration and Form, 41 Colum. L. REv. 799 (1941) [hereinafter cited as Fuller]; Patterson, An Apology for Consideration, 58 CoLum. L. REv. 929 (1958); von Mehren, Civil-Law Analogues to Consideration: An Exercise in Comparative Analysis, 72 HaRv. L. REv. 1009 (1959).

44 That function is, primarily but not exclusively, to identify those promises for whose breach the law will grant some remedy. See generally Henderson at 346; Sharp, Pacta Sunt Servanda, 41 Colun. L. REv. 783, 796 (1941); von Mehren, supra note 43. See text at notes 71.79 infra.

45 E.g., Patterson, supra note 43, at 939. 
as against one party might be found unconscionable, ${ }^{46}$ or one party might be able to raise the defense of the statute of frauds while the other would not. ${ }^{47}$

A more meaningful inquiry into the propriety of awarding full contract damages for breach of a promise enforced because of reliance requires a comparison of the possible reasons for doing so with the reasons why we award such damages for breach of contract. To the extent that the same factors operate in both circumstances, identical damages should be awarded.

In a landmark article on contract damages, ${ }^{48}$ Fuller and Perdue advanced two rationales for awarding an aggrieved contract promisee damages measured by the expectation interest, or expectancy. The first is that, assuming the object of the award to be compensation of the promisee for losses actually incurred through reliance, the award of the expectation interest is most likely to "cure" such losses. "It is a cure for these losses in the sense that it offers the measure of recovery most likely to reimburse the plaintiff for the (often very numerous and very difficult to prove) individual acts and forbearances which make up his total reliance on the contract." ${ }^{49}$ The second is that, by deterring breach, the award of the expectancy will operate to prevent losses caused by breach, and to promote "security of reliance" on business agreements. ${ }^{50}$ These rationales will be examined in order.

\section{A. The Cost of Reliance in a Commercial Context}

Some commentators have argued that the "cost of reliance" to the

46 UNIFORM COMMERCIAL CODE § 2-302. See generally Ellinghaus, supra note 22; Leff, Unconscionability and the Code-The Emperor's New Clause, 115 U. PA. L. REv. 485 (1967); Comment, Definition and Interpretation of Unconscionable Contracts (Uniform Commercial Code), 58 Dick. L. Rev, 161 (1954).

47 E.g., 2 Corbin $\S \S 282,524$. But see Uniform Commerctal Code $\S 2-201(2)$.

48 Fuller \& Perdue, supra note 3.

49 Id. at 60; cf. Lost Profits As Contract Damages at 992. Compensatory in rationale as it is, this notion is similar to an alternative explanation offered by Fuller and Perdue for the award of damages measured by the expectation interest, which they describe as an "institutional" or "economic" explanation: damages measured by the expectation interest might be proper in an institutional framework where "[e]xpectations of future values become, for purposes of trade, present values. In a society in which credit has become a significant institution ... the breach of a promise works an 'actual' diminution of the promisee's assets-'actual' in the sense that it would be so apprised according to modes of thought which enter into the very fiber of our economic system." Fuller \& Perdue at 59. They qualified this approach, however, with the observation that the tendency to assign present values to future promises may have been the creature of legal awards of the expectancy rather than the cause. Id. at 59-60.

50 Fuller \& Perdue at 61-62; 5 CoRbin $\$ 1006$; cf. Lost Profits As Contract Damages at $996 \&$ n.23. Fuller and Perdue termed the combination of rationale noted in the text a "juristic" explanation for the award of damages measured by the expectation interest, or "expectancy." 
promisee of a promise enforced because of reliance is measured by his tangible out-of-pocket expenditures, and that such a promisee is adequately compensated by reimbursement of these amounts. ${ }^{51}$ However, if one reason for awarding a contractual promisee damages measured by the expectation interest is the greater likelihood of compensating him for the "often very numerous and difficult to prove individual acts and forbearances which make up his total reliance," it is difficult to see why a different standard should be applied to reliance on a promise enforced because of reliance. Whether or not a traditional contract has been consummated, in any realistic sense a promisee who in a commercial context has acted in reliance on the strength of a promise will very likely have foregone opportunities to negotiate or contract with other parties. ${ }^{52}$

Consequently, even if we assume damages measured by the reliance interest to be appropriate for the promisee of a relied-upon promise, the goal of proper compensation could only be attained by inclusion of the promisee's total costs in such forms as the forbearance to secure alternative bargains between the moment the promise was made and the moment of its breach. Indeed, if gains prevented by reliance are included in the reliance interest, and normal rules of damage mitigation are applied, there is no reason why in a commercial context awards measured by the reliance interest should be substantially less than those measured by the expectation interest. ${ }^{53}$

The inclusion of gains prevented by reliance, or opportunity costs, in evaluating the reliance interest is more important to the commercial than the non-commercial promisee. When a commercial promise is enforced because of reliance, the actions of both the promisor and promisee are similar to those of the parties to a contract, since the

51 See generally authorities cited note 5 supra.

52 Cf. Lost Profits As Contract Damages at 1004. This may generate costs in such forms as capital or labor resources required to undergo a period of enforced idleness, or of the subsequent inability to enter into an agreement which depended upon the inclusion of a promise such as the one relied upon. The latter might occur when a subsequently revoked offer is included as a sub-offer in a bid on a prime contract. Normally it is quite difficult for the prime contractor to obtain a release from his bid without being held liable for breach, or to obtain a modification of the contract. Cf. State v. State Constr. Co., 203 Ore. 414, 280 P.2d 370, 378-9 (1955), although some rather spectacular exceptions seem to occur in favor of large, prime defense contractors. Even if the promisee can obtain a rescission of the prime contract he has lost the opportunity to bid on that particular contract.

53 Lost Profits As Contract Damages at 1004. Fuller and Perdue also admitted the possible propriety of including such elements in the computation of the reliance interest. Fuller \& Perdue at 57. But since, as previously noted, they assumed that the promises enforced under $\S 90$ would be gratuitous in nature, see note 17 supra, they neglected the possibility that such opportunity costs or gains prevented might constitute a significant element in evaluating the reliance interest as a measure of damages for commercial promises enforced because of reliance. 
conduct of both parties is prompted by a desire for mutual benefit through exchange. ${ }^{54}$ Consequently, despite the lack of a contract, the economic realities surrounding the transaction are likely to be such that the costs of reliance will closely approximate the costs which attend a breach of contract. The activities of a gratuitous promisee stand on a different plane. He is not normally engaged in a continuous pattern of searching out alternative promisors with whom to negotiate..$^{55}$ When he does rely on an occasional and fortuitous promise, his reliance will not entail foregoing the chance to rely on an alternative promise: the "opportunity cost" of reliance will be minimal. Moreover, the gratuitous promisee will normally perceive the cost of his reliance in terms of direct, out-of-pocket expenditures. ${ }^{58}$

It must be noted, however, that the equivalence between the cost of commercial reliance and the costs which attend a breach of contract is approximate, rather than exact. Recovery of the expectation interest for breach of contract gives the promisee the value of the promise actually broken. But the opportunity cost of reliance on a particular promise is not the value of the promise actually broken but the value of the lost opportunity-the next best alternative. To the extent that the promise relied upon is more valuable than the next best alternative, the reliance interest including opportunity costs will be less valuable than the expectation interest.

54 Cf. Fuller \& Perdue at 61-62; Fuller at 813, 815. See also Restatement (SeCond) of CoNTRACTs $\S 89 \mathrm{~B}(2)$, comment $e$, at 140-1 (Tent. Draft No. 2, 1965). Inasmuch as the fact or likelihood of reliance by the promisee is one of the primary reasons for the enforcement of promises contained in a sufficiently formal contract, it would be anomalous if on the one hand we refused to award damages measured by the expectancy for breach of a promise enforced solely because of action-in-reliance, while at the same time enforcing either by action for present breach or anticipatory repudiation a bilateral, executory business agreement without proof of actual reliance. Nonetheless we do enforce the latter sort of promise, partly because of the likelihood of reliance, Lost Profits As Contract Damages at 996; of. Fuller \& Perdue at 70, and partly because the agreement arises out of a business context. Since the making and keeping of such promises is thought to promote economic productivity through mutual exchange, the award of damages which encourage businessmen to honor those promises is thought to promote the same goals. Fuller at 815; cf. Fuller \& Perdue at 64-65.

55 That is, his conduct has little relevance to the fostering of economic productivity through exchange of economic values. Cf. Fuller \& Perdue at 65. An exception might be the charitable pledge which is most often the response to an extensive canvass for funds by the donee. E.g., Matter of Field, 11 Misc. 2d 427, 172 N.Y.S.2d 740 (1958). In such circumstances the typical result has been the award of the full amount of the pledge, no doubt in part because that represents the only rational measure of damages.

56 For example, if Williston's Johnny, see note 25 supra, were to spend $\$ 500$ to purchase a car in reliance on Uncle's subsequently revoked promise, Johnny's immediate concern upon revocation is the $\$ 500$ out-of-pocket expenditure, and not the additional $\$ 500$ promised by Uncle. 
Requiring proof of the "next best alternative" would obviously produce an inadministrable rule of damages in an already problematic area. ${ }^{57}$ Moreover, if we assume that the difference in value of alternatives is small, ${ }^{58}$ then we should expect this most accurate measure of the reliance interest to approximate more closely the value of the expectation interest than would reimbursement for out-of-pocket expenditures. In one set of circumstances, however, the difference between alternatives appears substantial. These are the firm offer problems, which typically involve the revocation of a sub-contractor's offer before acceptance, but after the prime contractor-offeree has been awarded the prime contract on a bid which included the subcontractor's offer. ${ }^{59}$ Usually the prime contractor will procure another subcontractor at a higher cost and complete the prime contract, seeking to hold the original subcontractor liable for the difference. ${ }^{60}$ Normally, the reason for the original subcontractor's revocation is that he has erred in his computations and made an offer to enter into a losing contract. Under these circumstances it may be argued that the award of full contract damages to the prime contractor might give him the windfall benefit of the subcontractor's mistake: the next highest bid for the subcontract would presumably have been computed without such a mistake and would have been substantially more costly. Consequently, so the argument goes, the prime contractor's profit would have been reduced accordingly.

This argument neglects the nature of the multiple contractor situation. Assuming that the prime contractor's profit represented a fixed component of the prime bid, his profit would be denied only if the cost added by correction of the sub-offer were greater than the difference between the next lowest prime bid and that actually submitted by the contractor. If the added costs were greater, then the prime contractor would not have been awarded the contract. But unless the added cost exceeded that amount, the prime contractor would have been awarded

57 Fuller \& Perdue at 60; Comment, Measure of Damages for Breach of a Contract Created by Action in Reliance, 48 YALE L.J. 1036, 1046 (1939); cf. Lost Profits As Contract Damages at 1008. But see Haveg Corp. v. Guyer, - Del. -, -, 226 A.2d 231, 234 (1968) (instruction limited recovery to "an amount compensating [plaintiff] for the loss occasioned from his reliance on Haveg's supposed promises and to a reasonable sum required to permit Guyer to rearrange his affairs upon discovery that no contract existed").

58 Normally, the more competitive the market in which the goods or services are traded, the smaller will be the difference in value between alternatives.

59 E.g., cases cited note 9 supra.

60 Id. Usually the plaintiff is unable to modify or rescind his prime contract without being held liable for breach. See, e.g., State v. State Constr. Co., 203 Ore. 414, 280 P.2d 370 (1955). 
the contract even without the benefit of the mistake, and would have earned his profit on the contract. ${ }^{61}$ If the added cost did render the prime bid noncompetitive, the prime contractor would presumably have had resources available which he might have attempted to employ by bidding on another contract. ${ }^{62}$ In the latter case, the most accurate measure of damages would again be the value of the next best alternative contract.

There are additional factors which favor the award of full contract damages in these cases. Since the subcontractor's mistake gave rise to the dispute, a court might well take into account policy objectives of deterring carelessness in the making of promises which will foreseeably induce reliance. ${ }^{63}$ In addition, the award of full contract damages typically yields a result which is simple to administer. The only neces-

61 This may be illustrated by reference to a simple graph.

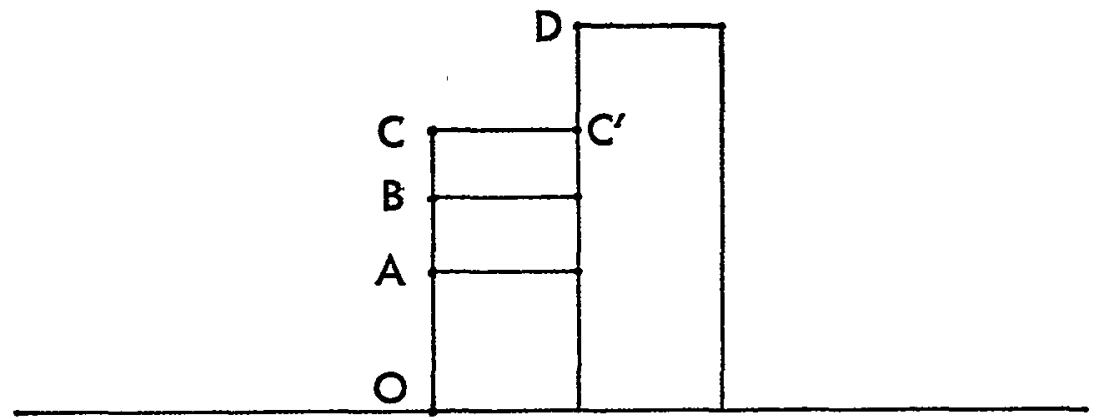

(1)

(2)

In the illustration above, the bars represent two bids on the same contract. 1 represents the bid of the successful bidder while 2 represents that of the next lowest bidder. Amount b? 1 represents the bid of a particular subcontractor, $A B$ represents the successful -iripated profit on the contract, and amount $O A$ represents all other costs

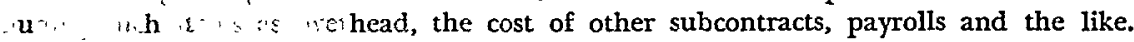
1 th u -ntract $r$ had made a mistake and the amount of his bid should have been, w t LC, but some greater amount, it does not necessarily follow that the prime contractor's profit would have been reduced on the contract. In fact the amount added by the correction of the sub-bid would have to exceed amount $C^{\prime} D$ for this possibility to arise. With an increase of any smaller amount the prime contractor would still have been awarded the contract and would have earned the same profit which he had originally anticipated, amount $\mathrm{AB}$. If the cost added by the correction exceeded $\mathrm{CD}$, then either the prime contractor would, by correct estimation, have had to reduce his profit on the prime contract or risk submitting a noncompetitive bid.

On this analysis it might be appropriate to limit the prime contractor's damages to no more than the difference between his bid and the next lowest bid; on the other hand, a failure to obtain this contract might have left the prime contractor in a position to bid successfully on an alternative and equally profitable contract.

62 Cf. Kunkle v. Jaffe, 47 Ohio L. Abs. 77, 71 N.E.2d 298 (1946).

63 Cf. Fuller \& Perdue at 374-5; see also Restatement (Srcond) of Contracts \& 90, comment $e$ and illustrations 12 and 13 at 170-1, 176 (Tent. Draft No. 2, 1965). But see text preceding notes $83-84 \& 149$ infra. 
sary computation is the difference between the price paid by the plaintiff and the price of the offer upon which he relied. In fact, this result is uniformly reached in reported cases. ${ }^{64}$

There is one general objection to the award of full contract damages in reliance-enforcement situations which goes less to the economic propriety of the award than to its potential results. It is that such awards may lead to a judgment for substantial lost profits against a promisor who has caused minor out-of-pocket expenditures in reliance, and who has not even had the benefit of a mutually binding bargain. ${ }^{6 \bar{s}}$ But notwithstanding the objective lack of mutuality, the nature of the transaction is such that both parties are contemplating the formation of an agreement with an eye to mutual benefit. ${ }^{66}$ More important, the possibility of disproportionate judgments is one about which the law has been uneasy even when a traditional contract exists. ${ }^{67}$ Rules regarding foreseeability, certainty, and actual causation have been formulated to reduce the possibility of disproportionate verdicts in contract cases. $^{68}$ It is true that such rules have not yet appeared in reliance-enforcement situations, partially because there have been few cases where their invocation has been necessary. ${ }^{69}$ The consistent ap-

64 E.g., Drennan v. Star Paving Co., 51 Cal. 2d 409, 333 P.2d 757 (1958); cf. Northwestern Eng'r Co. v. Ellerman, 71 S.D. 236, 23 N.W.2d 273 (1946); Raff Co. v. Murphy, 110 Conn. 234, 147 A. 709 (1929).

65 E.g., 65 Mich. L. Rev. 351, 353 (1966); Shattuck at 941-3.

66 See text and note at note 54 supra.

67 Lost Profits As Contract Damages at 995-6, 1011-3.

68 Fuller \& Perdue at 374-6; by far the most thorough discussion of these rules is to be found in Lost Profits As Contract Damages passim.

69 For example, in L. Albert \& Son v. Armstrong Rubber Co., 178 F.2d 182 (2d Cir. 1949) (L. Fand, C.J.), a buyer of machinery claimed as part of his damages the expenses which he had incurred in preparation for use of certain machines, relying on his contract with defendant by which the latter was to supply the equipment. Although these expenses were in no sense "part performance" of the contract, the buyer was permitted to recover the amounts without any mention of whether they were reasonably foreseeable to the seller. 178 F.2d at 189-91. But see 5 ConBIN $\S 1035$, text following n.50.5. See also Security Stove \& Mfg. Co. v. American Ry. Express Co., 227 Mo. App. 175, 51 S.W.2d 572 (1937). Occasionally it may be difficult for the buyer to prove the value of profits lost by virtue of the breach. See Security Stove \& Mfg. Co. v. American Ry. Express Co., supra; Burridge v. Ace Storm Window Mfg. Co., $69 \mathrm{~Pa}$. D. \& C. 184 (1949). Under such circumstances it may be proper to permit the buyer to prove as an alternative measure of damages his expenditures in preparation for use (termed "incidental reliance" by Fuller and Perdue and incorrectly categorized by Hand as "essential reliance" in L. Albert \& Son v. Armstrong Rubber Co., supra at 191; compare Fuller \& Perdue at 78) without regard to their foreseeability; but cf. 5 CORBIN \$ 1035.

A more plausible explanation for the absence of discussion of such questions as foreseeability, certainty, and the like in decisions enforcing promises because of reliance is that these questions are considered by the court in determining whether to apply $\S 90$. The words of the section, which require that the promisor "reasonably expect [his promise] to induce action or forbearance of a definite and substantial character" seem to subsume 
plication of contract damage rules to promises enforced because of reliance may lead to potentially disproportionate verdicts. It is submitted that if this happens the same limiting doctrines should and can be expected to operate as effectively as they do in contract cases.

\section{B. Action-In-Reliance and Freedom of Contract}

The second reason advanced for awarding damages measured by the expectation interest for breach of contract is that such damages will, by deterring breach, tend to prevent losses caused by the breach and promote "security of reliance" on business agreements.

Since the goal of "security of reliance on business agreements" necessarily means security of reliance on the promises contained in such agreements, we might inquire why that goal is not promoted by the award of damages measured by the expectancy for breach of all enforceable promises arising out of a business context. The answer seems to be that there are potential costs involved in attaining this goal: while the award of the expectancy would encourage businessmen to honor their commitments, it would also tend to discourage their making them. The latter result is particularly undesirable when the promises enforced arise out of the precontractual negotiating process which ultimately leads to agreement. ${ }^{70}$ It is within the context of these competing goals-promoting security of reliance on the one hand and preserving freedom of contract on the other-that we are obliged to examine the propriety of awarding damages measured by the expectation interest to a promisee who has acted in reliance.

Any particular basis of commercial promissory liability, of which the bargain theory of consideration is but one and action-in-reliance another, is merely a device which identifies a limited and particular group of promises for whose breach the law will grant a remedy. ${ }^{71}$ To the extent that any group so identified includes or excludes represen-

the question of foreseeability, if not also the question of certainty. Cf. note 35 supra. This requirement of foreseeability seems to be explicitly considered in reliance-enforcement decisions. E.g., N. Litterio \& Co. v. Glassman Constr. Co., 319 F.2d 736, 739 (D.C. Cir. 1963); Burridge v. Ace Storm Window Mfg. Co., 69 Pa. D. \& C. 184, 190 (1949). See also Boyer, Promissory Estoppel: Requirements and Limitations of the Doctrine, 98 U. PA. L. REv. 459, $461-70$ (1950). The absence of any discussion of questions of "certainty" and "causation" might also result from the fact that in decisions where this question might have arisen the problem was mooted by elimination of the damages on other grounds. See text at notes 138-46 \& 153-60 infra.

70 Fuller at 813; Patterson, An Apology for Consideration, 58 Colum. L. REv. 929, 943, 946 (1958); cf. Kessler \&. Fine, supra note 8, at 412. See also Cohen, The Basis of Contract, 46 HARv. L. REV. 553, 573 (1933).

71 E.g., 1 CoRBIN §§ 109-10; Fuller \& Perdue at 58; Llewellyn, What Price Contract?-An Essay in Perspective, 40 YALE L.J. 704, 738 (1931); von Mehren, supra note 43, at 1015 et seq. 
tations which are thought to be preliminary or tentative in character, each device will work its own accommodation between the goals sought to be achieved by the enforcement of commercial promises generallyand of particular relevance here, the promotion of security of reliance-and the need for minimizing restraints during preliminary negotiations. Clearly, some devices will better perform the task of limiting enforcement of what are intended to be preliminary representations than others. And the better a particular device performs this task, the more prepared we should be to award damages measured by the expectation interest for the promises which that device designates enforceable: by limiting the enforcement of preliminary representations, such devices will also limit the cost, in terms of impairing freedom of contract, of promoting security of reliance through the award of the expectation interest.

We most routinely award damages measured by the expectation interest for breach of business promise embodied in an agreement which contains return promises or performance-that is, consideration. Thus, it is probable that the requirement of consideration, which operates to designate a promise "contractual," results in a satisfactory accommodation between the goals sought by the enforcement of commercial promises and the need for minimizing restraints on freedom of action. ${ }^{72}$ We shall use that accommodation as a norm against which to compare how successfully some other basis of liability-in this case action-in-reliance by a commercial promisee-performs the same task.

Traditional wisdom of Anglo-American contract law is that private autonomy in the market place best regulates the terms of exchange. ${ }^{73}$ The law will not normally intervene to enforce a commercial promise unless it is embodied in an agreement containing an exchange of economic values. ${ }^{74}$ As a formal prerequisite to the enforcement of promises, consideration-the requirement of a bargained-for equivalent-operates to encourage certain desirable conditions with respect to the promises enforced; consequently, it also tends to minimize certain risks inherent in the enforcement of promises. ${ }^{75}$ First, to the extent that consideration provides evidence of the terms of the agreement in case of dispute, ${ }^{76}$ it minimizes the possibility that judicial intervention

72 Cf. Patterson, supra note 70 , at 946 .

73 E.g., Fuller at 806-10; Kessler \& Fine, supra note 8, at 409; Patterson, supra note 70, at 945 .

74 E.g., authorities cited note 13 supra; Patterson, supra note 70, at 945-7. Throughout this discussion the terms "bargain" and "agreement" will be used synonymously to mean bargain. But cf. Patterson at 944.

75 See generally Fuller passim; von Mehren, supra note 43, at 1016-7; Restatemenr (SECOND) OF Contracts $\$ 76$, comment $c$ at 16 (Tent. Draft No. 2, 1965).

70 Fuller at 800 . 
will effectively set the terms of the bargain differently from those to which the parties might have agreed if left to their own devices.77 Second, insofar as it requires some deliberation of a party contemplating the formation of an agreement, it reduces the possibility that hasty and imprudent conduct will result in liability. ${ }^{78}$ Finally, by providing a recognizable form into which promises intended to be binding may be cast, it impliedly operates to reduce inadvertent liability. ${ }^{79}$

The net effect of these factors is to identify the point of contract formation as one at which the consequences of transactional conduct are altered. Until that point is reached the promisor is encouraged to consider the consequences of entering into the agreement. Until that time he also remains free to deal with the other parties at arm's length, acting in his own best interests..$^{30}$ Most important is the fact that the point at which the bargain is struck is usually mutually identifiable to the parties. ${ }^{81}$ They themselves are aware of the extent to which they may act in their orw interests, and of the point at which their conduct has led to a binding obligation. The requirement of consideration thus operates to delineate an identifiable sphere of precontractual conduct free of legal restraint. Consequently, the award of expectation damages for breach of promises which are contractual in the sense that they are accompanied by consideration will promote the goal of security of reliance with a minimal impact on freedom of action.

When action-in-reliance operates as the basis of liability in an exchange context, a different group of promises will be enforced and we should expect a somewhat different accommodation between these two goals. The fact that the relied-upon promises arise in an exchange context, and that the parties' conduct is prompted by a desire for mutual benefit, indicates that the enforcement of such promises will in some

77 Kessler \& Fine, supra note 8, at 409 . This result is fostered only to the extent that we require the terms of the bargain to be "definite." See, e.g., Uniform Commerciar Code $\S$ 2-204(3); City Stores Co. v. Ammerman, 266 F. Supp. 766 (D.D.C. 1967), aff'd, 394 F.2d 950 (D.C. Cir. 1968). See also text at notes 101-5 infra.

78 Fuller at 800. Patterson, supra note 70, at 943, 949-52.

79 Fuller at 801; Patterson, supra note 70, at 949. Fuller has denominated these three desiderata the "evidentiary," "cautionary," and "channelling" functions, respectively, of consideration. Fuller at 800-1.

80 E.g., James Baird Co. v. Gimbel Bros., Inc., 64 F.2d 344 (2d Cir. 1933) (revocation of offer permitted after reliance but before acceptance); Rosenfield v. United States Trust Co., 290 Mass. 210, 195 N.E. 323 (1935) (failure to agree on minor term permitted promisor to withdraw without liability); Prince v. Miller Brewing Co., 434 S.W.2d 232, 237-8 (Tex. Civ. App. 1968) (revocation of franchise which was terminable at will permitted after reliance); cf. Edwards v. Walton, 308 S.W.2d 587 (Tex. Civ. App. 1957) (plaintiff's promise to repair without charge a building he had constructed held not binding).

81 But see Uniform Commercial Code § 2-204(2). 
degree promote security of reliance on business promises. ${ }^{82}$ Indeed, it may do so to a greater extent than the enforcement of a promise accompanied by consideration. Unlike the normal contract case in which breach may occur for any number of reasons, the motives behind the revocation of promises after reliance tend to be similar: in many instances the promisor will in some sense have been at "fault." Almost invariably, the reason for revocation of an offer after reliance is that the offeror has made an error in computing his bid and is about to find himself in a losing contract. ${ }^{83}$ In many instances involving reliance during precontractual negotiations, the promisor appeared to be acting negligently or in bad faith. ${ }^{84}$ To the extent that such factors predominate in motivating a promisor to retract a promise after reliance, the enforcement of relied-upon promises fulfills the additional deterrent function of promoting good faith action and diligence on the part of the promisor.

But since action-in-reliance designates a promise enforceable at some point prior to the moment of normal contract formation, ${ }^{85}$ it impliedly represents a departure from the notion that private autonomy determines what promises will be enforced. To the extent that the imposition of liability occurs during the course of precontractual negotiations, reliance enforcement also represents an intrusion on that sphere of activity left free of legal restraint by the requirement of consideration.

As a departure from the principle of private autonomy, liability for action-in-reliance is not, in the context of recent developments, unique. There have developed far too many judicial and legislative inroads on the principle for it to be said that the enforcement of private "legislation" is the sole function of the court in a contract decision. ${ }^{86}$ Anglo-

82 But cf. Fuller \& Perdue at 63-65, drawing the opposite conclusion, apparently on the assumption that only gratuitous non-commercial promises would be enforced under $\S 90$.

83 E.g., James Baird Co. v. Gimbel Bros., Inc., 64 F.2d 344 (2d Cir. 1933); N. Litterio \&. Co. v. Glassman Constr. Co., 319 F.2d 736 (D.C. Cir. 1963); text following notes 59-60 stcpra.

84 E.g., Chrysler Corp. v. Quimby, 51 Del. 264, 144 A.2d 123 (1958); cf. Goodman v. Dicker, 169 F.2d 684 (D.C. Cir. 1948).

85 Many, although not all, decisions involving promissory estoppel in commercial settings involve problems of contract formation. See generally Henderson, supra note 12. However, most of the decisions involving damage problems in the context of promissory estoppel do occur in the area of formation. E.g., Goodman v. Dicker, 169 F.2d 684 (D.C. Cir. 1948); Chrysler Corp. v. Quimby, 51 Del. 264, 144 A.2d 123 (1958). But see Peoples Nat'l Bank v. Linebarger Constr. Co., 219 Ark. 11, 240 S.W.2d 12 (1951). Moreover, the problem of distinguishing between damages measured by the expectation as opposed to the reliance interest will normally occur when promissory estoppel is employed to supplement normal rules of contract formation. Compare, e.g., Goodman v. Dicker, supra, with Peoples Nat'l Bank v. Linebarger Constr. Co., supra and text at notes 173-86 infra.

86 Cf. Fuller at 808-9; Sternaman v. Metropolitan Life Ins. Co., 170 N.Y. 13, 62 N.E. 763 (1902); but see, e.g., Stees v. Leonard, 20 Minn. 448, 451 (1874). 
American jurisdictions have universally refused to enforce certain promises which do not comply with the statute of frauds. Notions such as duress ${ }^{87}$ and unconscionability ${ }^{88}$ serve as weapons with which a court might refuse to honor an otherwise mutually binding agreement. Moreover, some of these incursions have also had the effect of intruding into the sphere of activity which the requirements of consideration would otherwise have protected from interference. For example, an imperfectly formed agreement might be enforced on a quasi-contractual basis to avoid unjust enrichment. There the absence of a bargain is irrelevant, since the circumstances may have been such that the promisee clearly acted with the expectation of compensation. ${ }^{80}$ And despite our putative insistence that negotiations proceed at arm's length until the bargain is struck, it has been suggested that American courts have devised their own requirements of good faith bargaining, ${ }^{90}$ of which liability for action-in-reliance may be one example.

The preceding developments, some of which are coming to be described collectively as a twentieth century "socialization"91 of the law of contracts, represent in part an expansion of the scope of social duty implicit in the law of civil obligation at the expense of private autonomy and individual freedom of contract. Viewed in this context, the fact that the expansion of promissory estoppel into the area of exchange imports a departure from the principle of private autonomy should not itself be of concern in determining the proper measure of damages. On the other hand, the existence of broad inroads on private autonomy does not resolve our difficulties, since few of these developments involve comparable damage problems. ${ }^{92}$ It remains necessary to

87 Cf., e.g., Vanderbilt v. Schreyer, 91 N.Y. 392 (1883); compare Lattimore v. Farsen, 14 Johns 330 (N.Y. Sup. Ct. 1817) and King v. Duluth, Missabe \&. Northern Ry. Co., 61 Minn. 482, 63 N.W. 1105 (1895) (recovery permitted on other grounds), with Schwartzreich v. Bauman-Basch, Inc., 231 N.Y. 196, 131 N.E. 887 (1921) and Watkins \& Son v. Carrig, 91 N.H. 459, 21 A.2d 591 (1941). See also Dawson, Economic Duress-An Essay in Perspective, 45 MrCh. L. REv. 253 (1947).

88 E.g., Uniform Commergial Code \& 2-302; Campbell Soup Co. v. Wentz, 172 F.2d 80 (3d Cir. 1948); Henningsen v. Bloomfield Motors, Inc., 32 N.J. 358, 161 A.2d 69 (1960). But see O'Callaghan v. Waller \& Beckwith Realty Co., 15 Ill. 2d 436, I55 N.E.2d 545 (1958). See generally Ellinghaus, In Defense of Unconscionability, 78 YaLE L.J. 757 (1969); Patterson, The Interpretation and Construction of Contracts, 64 CoLuM. L. REv. 833, 855-62 (1964) and authorities there cited.

89 .E.g., In re Crisan Estate, 362 Mich. 569, 107 N.W.2d 907 (1961). Compare Chase v. Corcoran, 106 Mass. 286 (1871), with Boston Ice Co. v. Potter, 123 Mass. 28 (1877).

90 See generally Kessler \& Fine, supra note 8.

91 . Ef. Ellinghaus, supra note 88 , at 765 . See the introduction to the chapter on third-party beneficiaries in the forthcoming revision of F. KESSLER \& M.P. SHARP, ConTracts-CasEs AND Materiars by Professors Kessler and Gilmore; Peoples Nat'l Bank v. Linebarger Constr. Co. 219 Ark. 11, 17, 240 S.W.2d 12, 16 (1951).

92 For example, when recovery is awarded on a theory of quasi-contract, it is normally 
examine the extent to which promissory estoppel operates to preserve freedom of action while promoting security of reliance on business promises.

Since action-in-reliance does designate a promise binding prior to the normal point of contract formation, it represents an intrusion into the sphere of conduct left free of restraint by consideration. What is more important, however, is the extent to which the promisee's actionin-reliance identifies, to the promisor, the limits within which he is free to deal at arm's length..$^{93}$ Alternatively, we may inquire whether the promisee's action-in-reliance provides a sufficiently ascertainable point at which to impose liability. ${ }^{94}$

Unlike the bargain, which is a mutually worked out formality, action-in-reliance seems to involve unilateral conduct by the promisee. It can be argued that the promissor's liability may well be inadvertent, and possibly unconsidered. Even in theory, however, this is not wholly true. Section 90 requires that the reliance be not only substantial ${ }^{95}$ but also reasonably foreseeable to the promisor. This latter requirement has been imposed with sufficient stringency for it to be said that actual foresight is virtually required. ${ }^{96}$ More importantly, the facts of so many cases in which action-in-reliance is the basis for commercial liability display bargaining conduct which has gone a long way towards traditional contract formation. When the promisee acts in reliance, events have arguably reached the point where both parties can recognize that they have or should have become bound. The promisee's recognition is expressed in his reliance. The promisor ought to recognize that liability may be imposed upon him because his conduct in

measured by the fair market value of the goods sold or services rendered. E.g., In re Crisan Estate, 362 Mich. 569, 107 N.W.2d 907 (1961). More typically, judicial incursions on freedom of contract take the form of refusing to enforce an otherwise binding agreement, as where a party is discharged from an oppressive agreement. C $f_{\text {., }}$ e.g., Vanderbilt v. Schreyer, 91 N.Y. 392 (1883). Even when such exculpatory clauses as warranty restrictions are invalidated, the damages awarded are those which, but for the restriction, would have been prescribed by law. E.g., Henningsen v. Bloomfield Motors, Inc., 32 N.J. 358, 161 A.2d $69(1960)$.

93 See Fuller at 805-6.

94 See text following notes $80-81$ supra. It should be noted that to assert that the bargain is a desirable point at which to impose liability because it is recognizable involves something of a tautology: it is a recognizable moment in the negotiating process in part because judicial enforcement of bargains has led us to expect that it is the point at which liability will be imposed. Cf. Fuller \& Perdue at 58-59.

95 But see the redraft of $\$ 90$ proposed for the Restatement (Second) of Contracts, text and notes at notes 106-19 infra.

96 E.g., Corbit v. J. I. Case Co., 70 Wash. 2d 522, 539, 424 P.2d 290, 301 (1967); cf. N. Litterio \& Co. v. Glassman Constr. Co., 319 F.2d 786, 739 (D.C. Cir. 1963); Drennan v. Star Paving Co., 51 Cal. 2d 409, 415, 333 P.2d 757, 760 (1958). 
fact induced the promisee's reliance. ${ }^{97}$ It seems irrelevant to object that the promisor did not have the benefit of a "mutually binding" agreement ${ }^{98}$ because the promisee's reliance binds him factually, if not legally, to the bargain. ${ }^{99}$ Moreover, the promisor is protected from being arbitrarily bound by the combined requirements of substantiality and foreseeability, and by the frequently imposed requirement that the promisee's reliance be reasonable under the circumstances. ${ }^{100}$ These rather stringent requirements strongly suggest that if and when liability is imposed for action-in-reliance it will not be unexpected.

Granting that action-in-reliance may identify, as well as does the requirement of consideration, a sphere of conduct free of restraint, consideration also operates to provide some evidence of the terms of the agreement. ${ }^{101}$ The possibility remains that imposition of liability for promises made in the course of precontractual negotiations may set terms of the bargain different from those to which the parties themselves would have agreed. To the extent that it remains desirable for private autonomy to establish the terms of exchange, this result may be thought unfortunate. But as a practical matter, a glance at the present law on indefiniteness indicates that courts have been imposing bargains on parties for some time. While we once avoided enforcing a contract if any material terms were left unspecified, ${ }^{102}$ courts now routinely award damages ${ }^{103}$ for, and decree specific performance ${ }^{104}$ of,

97 E.g., Wheeler v. White, 398 S.W.2d 93, 96 (Sup. Ct. Tex. 1965) ("promises designedly made to influence the conduct of the promisee, tacitly encouraging his conduct"); Burridge v. Ace Storm Window Co., 69 Pa. D. \& C. 184, 190 (1949) ("defendant's promise was one intended and likely to induce and did induce action on the part of the plaintiff of a definite and substantial character").

98 E.g., 65 Mich. L. Rev. 351,356 (1966).

99 A possible exception occurs in the area of firm offers, where the prime contractor has occasionally been held not bound to the subcontractor after award of the prime contract but before acceptance of the subcontract. Williams v. Favret, 161 F.2d 822 (5th Cir. 1947); Milone \& Tucci, Inc. v. Bona Fide Builders, 49 Wash. 2d 363, 301 P.2d 759 (1956).

100 E.g., Robert Gordon, Inc. v. Ingersoll-Rand Co., 117 F.2d 654, 661 (7th Cir. 1941); Union Tank Car Co. v. Wheat Bros., 15 Utah 2d 101, 387 P.2d 1000 (1964); Ted Spangenberg Co. v. Peoples Natural Gas, 305 F. Supp. 1129, 1134 (S.D. Iowa 1969) (Hanson, J.); cf. N. Litterio \& Co. v. Glassman Constr. Co., 319 F.2d 736, 739 (D.C. Cir. 1963); Hoffman v. Red Owl Stores, Inc., 26 Wis. 2d 683, 692, 133 N.W.2d 267, 272 (1965) (approved instruction required promisee to have exercised "ordinary care"); Henderson at $361,385$.

101 Text at notes 75-77 supra and authorities there cited.

102 E.g., Kearns v. Andree, 107 Conn. 181, 139 A. 695 (1928) (partial recovery permitted on other grounds); Rosenfield v. United States Trust Co., 290 Mass. 210, 195 N.E. 323 (1935); Sun Printing \& Publishing Ass'n v. Remington Paper \& Power Co., 235 N.Y. 338, 139 N.E. 470 (1923).

103 E.g., Bettancourt v. Gilroy Theatre Co., 120 Cal. App. 2d 364, 261 P.2d 351 (1953); Fairmount Glass Works v. Crunden-Martin Woodenware Co., 106 Ky. 659, 51 S.W. 196 (1899); Foley v. Classique Coaches, Ltd., [1934] 2 K.B. 1. See also Uniform Commerciad CODE $\S \S 2-204(3), 2-305,-310$. 
contracts which once would have been dismissed as indefinite and unenforceable. By analogy, one might treat any commercial promise enforced because of reliance as an offer more or less definite in its terms. To the extent that such promises are sufficiently definite to have supported a recovery of damages measured by the expectation interest had they been accompanied by traditional consideration, identical damages should be awarded when they are enforced because of action-in-reliance.

Conversely, it has been noted that when recovery is sought for breach of an indefinite agreement, there is some tendency to award damages measured by the reliance interest (without inclusion of opportunity costs) rather than the expectation interest. ${ }^{105}$ To the extent that the law retains such misgivings with respect to awards for breach of an indefinite agreement, awards for breach of a promise enforced because of action-in-reliance might be similarly limited to a recovery of the reliance interest, excluding opportunity costs. However, such a limitation would be justifiable only to the extent that a similar result obtained with respect to an indefinite agreement.

Measured against the norm of the doctrine of consideration, then, it is apparent that action-in-reliance, as it is presently used in the enforcement of business promises, functions quite well to insulate truly preliminary representations from the imposition of liability. It is of course true that reliance liability, strictly speaking, is a departure from the notion that private autonomy, expressed in mutual agreements, determines what promises will be enforced. But despite the absence of consideration the combined requirements of foreseeability, reasonableness, and substantiality indicate that the imposition of liability for action-inreliance will be no more inadvertent than liability for breach of contract, and will protect the promisor from being unilaterally and arbitrarily bound by the promisee. Thus the costs, in terms of impairing freedom of contract, of commercial reliance liability seem to be little more than they would be in the case of contractual liability. And, as is the case with contractual liability, commercial reliance liability will also tend to promote security of reliance. Accordingly, since enforcement of commercial promises because of reliance works a satisfactory accommodation between the goals of promoting security of reliance and preserving freedom of contract, it would seem no less appropriate to

104 E.g., City Stores v. Ammerman, 266 F. Supp. 766 (D.D.C. 1967), aff'd, 394 F.2d 950 (D.C. Cir. 1968); Morris v. Ballard, I6 F.2d 175 (D.C. Cir. 1926).

105 Kearns v. Andree, 107 Conn. 181, 139 A. 695 (1928); Burridge v. Ace Storm Window Mfg. Co., 69 Pa. D. \& C. 184 (1949); Fuller \& Perdue at 394-6; cf. Terre Haute Brewing Co. v. Dugan, 102 F.2d 425 (8th Cir. 1939). 
award damages measured by the expectation interest for breach of such promises as for breach of contractual promises.

\section{Reliance Damages and the Second Restatement}

In light of the foregoing analyses, it is the position of this comment that damage awards for commercial promises enforced because of reliance should be determined by the rules applicable to actions for breach of contract. This position is implicitly at odds with the scheme developed in the sections on action-in-reliance in the proposed Second Restatement of Contracts. ${ }^{106}$ That document contains two provisions, one covering reliance on promises, ${ }^{107}$ the other covering reliance on offers. ${ }^{108}$ The latter is clearly in response to the numerous firm offer cases which have been reported. ${ }^{109}$ The former would appear to cover all other cases involving action-in-reliance, including promises arising out of both commercial and gratuitous contexts.

The articulation of a separate section for relied-upon offers is not in itself objectionable. However, other changes are proposed. Section 90 is amended by deleting the requirement that the action-in-reliance be of a "definite and substantial character."110 The comments suggest that the deletion is intended to foster a flexible approach to this condition, requiring definite and substantial reliance in some circumstances but not others. ${ }^{111}$ Under what circumstances this requirement is to be imposed is left unclear. While the requirement of substantiality might well be dispensed with for some promises, its explicit retention with respect to promises arising out of commercial transactions is desirable..$^{112}$ As noted above, the combined requirements of substantiality, reasonableness, and foreseeability of the reliance fulfill the deterrent and

106 Restatement (SECOND) of Contracts (Tent. Draft No. 2, 1965). See generally Braucher, Freedom of Contract and the Second Restatement, 78 YALE L.J. 598 (1969). See also text and notes at notes 149-50 infra.

107 Id. § 90, at 165:

A promise which the promisor should reasonably expect to induce action or forbearance on the part of the promisee or a third person and which does induce such action or forbearance is binding if injustice can be avoided only by enforcement of the promise. The remedy granted for breach may be limited as justice requires.

108 Id. $\S 89 \mathrm{~B}(2)$, at 135 :

An offer which the offeror should reasonably expect to induce action or forbearance of a substantial character on the part of the offeree before acceptance and which does induce such action or forbearance is binding as an option contract to the extent necessary to avoid injustice.

109 Cases cited note 20 stcpra.

110 Compare note 107 supra, with note 1 supra.

111 Restatement (SECOND) of Contracts $\S 90$, comment $b$ at 166 (Tent. Draft. No. 2, 1965).

112 The drafters seemed to recognize this in retaining the requirement with respect to offers enforced under $\$ 89 \mathrm{~B}(2)$ which will normally arise out of commercial transactions. 
channeling functions which in the absence of action-in-reliance would have been performed by the requirement of consideration. ${ }^{113}$ By dispensing with the requirements of substantiality for the commercial promises to be enforced under the new section 90 , one increases the risk that these functions will not be fulfilled.

There are additional alterations. Section 90 has been further amended by providing that "[ $t]$ he remedy granted ... may be limited as justice requires."114 This apparently adopts a flexible approach ${ }^{115}$ to damages for all section 90 promises which, as argued above, is inappropriate in commercial contexts. But the drafters have added to the confusion by inserting in section $89 \mathrm{~B}(2)$ the provision that a relied-upon offer is binding "to the extent necessary to avoid injustice." 116 If the drafters intended by this language to adopt a flexible approach to damages for an $89 \mathrm{~B}(2)$ offer as well, one may with temerity inquire why they chose to do so in language different from that contained in proposed section 90 . A comparison of the comments to the two sections grudgingly permits the inference that the award of normal contract damages is slightly preferred as to a section $89 \mathrm{~B}(2)$ offeree, and the "flexible" approach of that section is not quite as "flexible" as the approach to be taken under section 90.117 This particular distinction does not, however, emerge from a comparison of the language of the two provisions. A more fundamental criticism is that the adoption of any flexible approach with respect to damages awarded under $89 \mathrm{~B}(2)$ is doctrinally and decisionally unwarranted. Since almost all offers as defined in the Restatement arise out of exchange contexts, an offeree recovering under $89 \mathrm{~B}(2)$ should be entitled to damages measured by normal contract rules. Moreover, the flexible approach to damages for relied-upon offers is inconsistent with the results in all of the firm offer cases. 118

It is unnecessary to belabor these criticisms. If the proposed Second Restatement is to be carried into final form, these provisions should undoubtedly be reworked. At a minimum, the last seven words of the proposed $89 \mathrm{~B}(2)$ should be deleted. Furthermore, it would be desirable to retain explicitly the requirement of substantiality of reliance with

\footnotetext{
113 See text and notes at notes 75-79 \& 95-100 supra.

114 Compare note 107 supra with note I supra.

115 See text and note at note 8 supra.

116 See note 108 stipra.

117 Compate Restatearent (SECOND) of Contracts § 89B(2), comment $e$ at 140-2 (Tent. Draft No. 2, 1965), with id. § 90, comment $e$ at 170-2.

118 See text and notes at notes 59-64 supra and notes 121-6 infra. It should also be noted that firm offers enforced under \$ 2-205 of the UNIFORM CoMmercinl CoDE are not accorded special treatment with respect to damages.
} 
respect to all commercial promises which are not offers, and to prescribe damages for breach of such promises according to the normal damage rules of the Restatement. These goals might be achieved by treating reliance upon offers and commercial promises in a single subsection such as is set out in the footnote. ${ }^{119}$

The number of decisions involving the question of damages for breach of a promise enforced because of reliance is understandably limited. Of the increasing number of cases involving promissory estoppel, many, being the first such cases in a particular jurisdiction, have involved pre-trial motions dismissing the complaint. ${ }^{120}$ Of the relatively few cases involving damage claims, a number are consistent with the position taken by this comment. There are some decisions which are consistent on their facts if not their rationales. In addition, there are a growing number of cases which suggest that promissory estoppel may be evolving into a doctrinal device by which to limit damages. This inference is initially drawn from an examination of decisions where the case might well have been decided on traditional contract grounds, the resort to promissory estoppel appearing unnecessary. The analysis is then extended to another type of decision in which, although the use of promissory estoppel is appropriate, the resulting award is determined by rather strained methods.

\section{A. Firm Offer Cases}

As suggested earlier, hesitation about applying normal contract rules of damage is least warranted when the parties to the action were close to striking a bargain of their own accord. ${ }^{121}$ The most frequent instance involves reliance upon an unconditional offer to contract. Here the propriety of the normal rule of contract damages has been unques-

119

$\S 90$. (1) (a) An offer to enter into a contract, or

(b) A promise made with a view to the consummation of a contract, or

(c) A promise made in the performance of an existing agreement,

which the offeror or promisor should reasonably expect to induce action or forbearance of a definite and substantial character on the part of the offeree or promisee and which does induce such action or forbearance is binding if injustice can be avoided only by enforcement of the offer or promise.

(2) A promise, other than a promise described in subsections 1 (a), (b), or (c) of this section, which the promisor should reasonably expect to induce action or forbearance on the part of the promisee and which does induce such action or forbearance is binding to the extent, if any, necessary to avoid injustice.

$120 \mathrm{Cf}$. Henderson at nn.44-46.

121 See text at notes 73-83 \& 101-5 supra. 
tioned. In Drennan v. Star Paving Co., ${ }^{122}$ the Supreme Court of California had no qualms over the possibility that normal contract damages would give the plaintiff the windfall benefit of the defendant's mistake. The court felt that the defendant's obligation to exercise due care with respect to the preparation of a bid upon which plaintiff would foreseeably rely outweighed the existence of the mistake and supported the decision to grant relief. ${ }^{123}$ Noting that the plaintiff had, as required, exercised reasonable care in seeking the lowest bidder on reletting the contract, ${ }^{124}$ the court affirmed the decision awarding the difference between the original bid and the bid as relet. In somewhat similar circumstances the Supreme Court of South Dakota applied the statute which prescribed the measure of damages for breach of contract. ${ }^{125}$ It is somewhat surprising, in view of the controversy which exists elsewhere, that these two cases hardly questioned the measure of damages. The explanation of this probably can be found in the ease of administration which the contract rule provides in such cases. ${ }^{126}$

\section{B. Franchise Cases}

At the other end of the spectrum from cases involving reliance on an offer are cases involving requests for damages because of reliance on promises made early in the course of precontractual negotiations. It was suggested above that under such circumstances the possibility of imposing undue burdens upon freedom of contract might generate legitimate concern over the question whether to award damages measured by the expectation interest. ${ }^{127}$

In Chrysler Corporation v. Quimby,,$^{128}$ plaintiff was a minor shareholder in an automobile dealership operated on a franchise from the Chrysler Corporation which was subject to ninety-day termination. When the operator of the franchise died, the plaintiff entered into negotiations with Chrysler with an eye to obtaining the franchise himself and continuing business under the same name. Chrysler imposed certain conditions on the award of the franchise, among them the purchase of all outstanding stock including that owned by the deceased's widow. This was done despite Chrysler's apparent intention

12251 Cal. 2d 409, 333 P.2d 757 (1956).

$123 \mathrm{Id}$. at $416,333 \mathrm{P} .2 \mathrm{~d}$ at 761 .

124 Id. at 417, 333 P.2d at 761. See also Raff Co. v. Murphy, 110 Conn. 234, 242 3, 147 A. 709, 712 (1929), holding that under analogous circumstances the prime connall " plaintiff was not obliged to mitigate damages by withdrawing its bid on the prime contrart and forfeiting its performance bond.

125 Northwestern Eng'r Co. v. Ellerman, 71 S.D. 236, 23 N.W.2d 273 (1946).

126 See text at notes 63-64 supra.

127 See generally text at notes 73-105 supra.

12851 Del. 264, 144 A.2d 123 (1958). 
ultimately to grant the franchise to another. After the plaintiff had acquired sole control of the franchise, Chrysler terminated negotiations and plaintiff sued. Among other things, he sought loss of three months' profits from operation of the dealership. Despite defendant's argument that such profits were unavailable under reliance recovery, ${ }^{129}$ the court not only disagreed but found that competent evidence had been produced to support the claim, based on the prior performance of the dealership. ${ }^{130}$

It appears from the opinion that not only was testimony concerning the negotiations in dispute, but the final terms of the franchise were not agreed upon. The court resolved this difficulty by fiat, asserting merely that Chrysler had evidenced an intention to be bound. It did not advert to the possibility that a difference between the terms of the old and the new franchises might undermine the competence of the proof of lost profits. It has been suggested above that such difficulties might be approached alternatively by analogy to the contemporary treatment of allegedly indefinite agreements. ${ }^{131}$ Among recent cases, one can find numerous decisions in which major terms of an agreement were filled in by a court by reference to other agreements which, although similar, were not identical. ${ }^{132}$ A fortiori, it would seem the decision to award Quimby the lost profits is correct. Not only is it likely that Chrysler's terms were similar from franchise to franchise, but the decision effectively involved the renewal of an old, rather than the grant of a new, franchise.

Hoffman v. Red Owl Stores, Inc. ${ }^{133}$ involved an action for damages resulting from the termination of protracted negotiations for the grant of a grocery store franchise. During the course of the negotiations, Hoffman, the prospective grantee, had taken steps to prepare for the commencement of operations. One such step was the purchase of a small store in which he could acquaint himself with the grocery business. As negotiations proceeded, defendant's representatives urged him to sell his store although the profitable months were just approaching. When the defendant suddenly increased the capital contribution which it would require of Hoffman, the latter abandoned the discussions. He subsequently sued, seeking among other things the loss of profits on the smaller grocery business which, at defendant's urging, he had sold for

12951 Del. at 283-4, 144 A.2d at 134. This argument was based upon Goodman $v$. Dicker, discussed in text at notes 138-50 infra.

$130 \mathrm{Id}$.

131 See text at notes 101-5 supra.

132 E.g., City Stores Co. v. Ammerman, 266 F. Supp. 766 (D.D.C. 1967), aff'd, 394 F.2d 950 (D.C. Cir. 1968).

13326 Wis. 2d 683, 133 N.W.2d 267 (1965). 
a small profit. When the jury returned a verdict which included some $\$ 16,000$ for the lost profits, the trial court ordered a new trial on that issue. The Supreme Court of Wisconsin sustained this order, agreeing that "Hoffman could not recover for any loss of future profits."184

Notwithstanding this holding, it is difficult to agree that Hoffman represents an explicit preference for the reliance interest over the expectation interest as a measure of damages for a promise enforced because of reliance. ${ }^{135}$ First, the facts of the case suggest that the court did not completely exclude recovery of profits lost by virtue of the sale of the business. Despite plaintiff's realization of a small gain on the sale of the store, the court agreed that there should be a new trial on the issue of damages. In so doing, it also agreed that plaintiff was entitled to recover the "difference between the sales price received and the fair market value of the assets sold, giving consideration to any goodwill attaching thereto by reason of the transfer of a going business." ${ }^{136}$ This is intriguing: on the one hand the court adverted to no evidence that the business had been sold at a distressed price. More important, recovery of the fair market value of the store would presumably give plaintiff no less than the value of the profits lost discounted to the time at which the business was sold. In effect he was permitted to recover the lost profits but retroactively was required to mitigate his damages by having reinvested the proceeds of sale.

Second, it is surely relevant to note that the question whether to award lost profits at all did not even involve a distinction between the reliance and expectation interests. ${ }^{137}$ That question would have arisen had the plaintiff sought to recover profits lost by virtue of his inability to commence business in the Red Owl store. The damages actually claimed by the plaintiff, including the claim for profits lost on the sale of the collateral business, all involved elements of the cost of his reliance on the promise that the Red Owl franchise would be granted. In reality, the profits dispute in Hoffman involved the question of the proper measure of the reliance interest, not whether to award damages measured by the reliance or expectation interest.

\section{G. Decisions Limiting Damages}

There are, of course, decisions in which courts have refused to award damages measured by the expectation interest. The most prominent appears to be Goodman $v$. Dicker, ${ }^{138}$ also involving the prospective

134 Id. at 700,133 N.W.2d at 276.

135 Cf. 65 MrCH. L. REv. 351 (1966).

13826 Wis. 2d 683, 700-1, 133 N.W.2d 267, 276.

13765 MICH. L. REv. 351 (1966) to the contrary notwithstanding.

138169 F.2d 684 (D.C. Cir. 1948). 
grant of a franchise, this time for the sale of radios. Defendants, local distributors for a manufacturer, had represented to plaintiffs that the franchise, which was to be terminable at will, would be granted and that some thirty to forty radios would be shipped. These were never delivered and the franchise was withheld, whereupon plaintiffs sued, seeking $\$ 1,150$ for expenditures made in reliance on defendants' representation and $\$ 350$ for anticipated profits on the radios which had not been delivered. The trial court held that the defendants were estopped from denying the existence of a contract and entered judgment for $\$ 1,500$. The Court of Appeals for the District of Columbia modified the award by eliminating the claim for anticipated profits and affirmed the judgment, stating that the "true measure of damages is the loss sustained by expenditures made in reliance upon the assurance of a dealer franchise."139 This case has been subsequently cited, often by way of dicta, for the proposition that anticipated profits may not be recovered where reliance is the ground for enforcement. ${ }^{\mathbf{1 4 0}}$

What is troublesome about the decision is not so much the elimination of the claim for lost profits, but rather the assertion that eliminating the claim was dictated by the fact that the cause of action was based upon reliance. Indeed, it is likely that the same result would have obtained under normal contract damage rules. First, unlike the franchise in Quimby which contained a ninety-day termination clause, the franchise in Goodman was terminable at will. Subject to the frequently imposed requirement of good faith conduct, ${ }^{141}$ termination of the agreement prior to shipment of the radios would have been consistent with Quimby in which lost profits were recovered for only the ninety-day period during which the franchise would have been irrevocable..$^{142}$ Second, unlike Quimby, Goodman involved a claim for profits lost in respect of a new business. There has been a traditional reluctance to award damages based upon claims for profits which might have been earned by a new enterprise which was prevented or delayed from commencing operations. ${ }^{143}$ If, unless uncontestably proven, such profits are thought too "speculative" to constitute an element of recovery in normal contract actions, the same limiting rule could be expected to

139 Id. at 685 .

140 E.g., L.S. Good \& Co. v. H. Daroff \& Sons, Inc., 279 F. Supp. 925, 927 (N.D. W. Va. 1968); Chrysler Corp. v. Quimby, 51 Del. 264, 144 A.2d 123 (1958); Wheeler v. White, 398 S.W.2d 93 (Sup. Ct. Tex. 1965), discussed at notes 152-7 infra.

141 See, e.g., Henderson at nn.103-9. But see, e.g., Prince v. Miller Brewing Co., 434 S.W.2d 232, 237-8 (Tex. Civ. App. 1968).

14251 Del. at 284, 144 A.2d at 134.

143 E.g., Evergreen Amusement Corp. v. Milstead, 206 Md. 610, 112 A.2d 901 (1955). See generally Lost Profits As Contract Damages at 1012-5. 
operate with no less force where reliance forms the basis for enforcement. 144

Perhaps the most persuasive traditional rationale for the result in Goodman is that the award of both reliance expenditures and lost profits might well have given plaintiff double recovery. He would have been entitled to both amounts only if the gross profit on the sale of the radios would have been sufficient to have recouped the full $\$ 1,500.145$ If the gross profit were less than $\$ 1,500$, then even if the franchise had been granted, the thirty radios shipped, and the franchise then terminated, plaintiff would not have both recouped his reliance expenditures and made the profit which he also claimed as damages. Under such circumstances, normal contract rules dictate that the plaintiff revert to out-of-pocket expenditures as an alternative measure of recovery, ${ }^{146}$ precisely the result achieved in Goodman.

To say that traditional contract rules of damages probably would have rendered a result identical with that reached on other grounds by the court in Goodman is simply to say that the common law of contract damages has already recognized the problems generated by similar fact situations, and for policy reasons has already evolved a method of dealing with such problems. The policy behind prohibiting double recovery is obviously a desire to avoid putting "the plaintiff in a better position than he would have occupied had the contract been fully performed."147 The rule which prohibits proof of recovery of profits which might have been earned from a new business rests in the recognition that it is difficult to demonstrate that a new business, for which there are no records of prior performance, would have been successful. ${ }^{148}$ Indeed, it is possible, if not likely, that in arriving at its decision, the court in Goodman was responding to one or more of these policies. Consequently, despite the questionability of the court's rationale, the result is sound.

However, taken as standing simply for the proposition that damages for breach of a promise enforced because of action-in-reliance are properly measured by the reliance rather than the expectation interest,

144 Text and notes at notes 67-69 supra.

145 For a gross profit of this amount to have been realized on the sale of thirty to forty radios, the average difference between retail and wholesale price would have to have been approximately forty to fifty dollars. Assuming a retail markup of fifty to twenty-five per cent, this would indicate an average unit retail price of eighty to two hundred dollars, which seems unlikely at 1946 prices.

146 1A CoRBIN § 205 n.51; 5 CoRBIN $\S$ 1035-6; cf. Henderson, text and notes at nn.106-7. See also L. Albert \& Son v. Armstrong Rubber Co., 178 F.2d 182 (2d Cir. 1949), discussed at note 69 supra.

147 Fuller \&: Perdue at 79; 5 CoRBrN § 1036.

148 Cf. Lost Profits As Contract Damages at 1013-4. 
Goodman's subsequent history is worthy of note. For example, the drafters of the Second Restatement have combined Goodman and Quimby and emerged with the proposition that where a promise is enforced because of reliance and the promisor has not acted in patent bad faith, damages ought to be measured by the reliance interest; but where circumstances are aggravated by opportunistic conduct on the part of the promisor such as that evidenced in Quimby, damages ought properly to be measured by the expectation interest. ${ }^{149}$

Certainly this distinction is plausible. It is, however, unpersuasive. On the one hand, as with most promises enforced because of reliance, the revocation by the promisors in both Goodman and Quimby involved a certain element of fault..150 Unless the "aggravated circumstances" in the latter decision rose to the level of a recognizable tort, ${ }^{151}$ it is difficult to see why a different measure of damages should depend upon the marginal difference in the degree of fault evidenced by the respective conduct. More important, traditional contract rules of damages, wholly neglected by the drafters, provide a more convincing explanation for the result in Goodman.

A more interesting offspring of Goodman is the case of Wheeler $v$. White. ${ }^{152}$ Defendant contracted in writing either to loan or to secure a loan for the plaintiff for the purpose of razing buildings on plaintiff's land and constructing a new one. The defendant was to receive a fee of $\$ 5,000$, and the loan was to bear interest at "not more than $6 \%$ per annum." On the strength of this contract, plaintiff razed the existing structures, which had a value of some $\$ 60,000$. When the defendant refused to obtain or provide the loan, plaintiff was unable to secure alternative financing, whereupon he sued to recover the value of the buildings destroyed, architectural fees, and loss of anticipated profits from the new building. The action was pleaded alternatively on a theory of contract and promissory estoppel. The Texas Court of Civil Appeals upheld the trial court's dismissal of both counts, ${ }^{153}$ while the Supreme Court of Texas reinstated the reliance count, indicating that the damages would be limited to the value of the buildings razed and the architectural fees. ${ }^{154}$

The dismissal of the contract count is problematic. The reason given by the court of civil appeals was that since the contract specified interest

149 RESTATEMENT (SECOND) of CoNtracts $\S 90$, illustrations 12 and 13 at 170-1 (Tent.

Draft No. 2, 1965).

150 See text at notes 83-84 supra.

161 Cf. Drennan v. Star Paving Co., 51 Cal. 2d 409, 416, 333 P.2d 757, 761 (1958).

152398 S.W.2d 93 (Sup. Ct. Tex. 1965).

153 Wheeler v. White, 385 S.W.2d 619 (Tex. Civ. App. 1964).

$15 \pm 398$ S.W.2d at 97. 
at "not more than" six per cent, and failed to specify how the principal was to be repaid, it was indefinite. Although these infirmities seem trivial, there was the additional factor of a recent precedent in which similar defects had rendered a contract indefinite. ${ }^{155}$ The latter decision had been vigorously criticized ${ }^{156}$ and, as a concurring judge pointed out, had held only that the agreement was too indefinite to be specifically enforced. Since Wheeler involved a request for damages, the concurring justice would have limited the prior decision and upheld the contract count in Wheeler. ${ }^{157}$

The only material distinction between the contract and reliance counts was the damage limitation explicitly appended to the latter. It is noteworthy that, even though the recovery of lost profits was theoretically available under the contract count, ${ }^{158}$ that recovery might practically have been foreclosed: proceeding under a contract theory, plaintiff would have been hard put to present sufficient evidence of the profitability of the new venture to have satisfied the strictures of the certainty rule. ${ }^{159}$ But the court took pains to divorce its holding from the certainty rule, pointing out that plaintiff could not recover lost profits under the reliance count no matter how persuasive the available proof. ${ }^{160}$ It is possible that the court permitted plaintiff to proceed only upon the reliance count, not out of doctrinal or precedential compulsion, but rather because, by dismissing the contract count and reinstating the reliance count, it could completely and conveniently prohibit the recovery of lost profits simply by following the "rule" of Goodman v. Dicker.

The reinstatement of the reliance count may be explored from

155 Bryant v. Clark, 163 Tex. 596, 358 S.W.2d 614 (1962).

156 5A CORBIN \& 1174, n.7.

157398 S.W.2d at 98 (concurring opinion).

158 Although historically there has been some reluctance to award damages other than interest rate differentials for breach of an agreement to lend money, commentators, e.g., 5 Corbin \& 1078, have favored, and courts have moved towards, awarding normal damages for breach of such agreements. Moreover, Texas courts had long since sanctioned the recovery of damages measured by lost profits for breach of a loan agreement. National Bank of Cleburne v. M.M. Pittman Roller Mill, 265 S.W. 1024 (Tex. Com. App. 1924), held that where a bank knew that the money which it had contracted to lend plaintiff was to be used to purchase wheat for milling purposes, plaintiff could recover from the bank damages sustained when the bank refused to loan the money and plaintiff was unable to secure the wheat. Indeed, it may be hypothesized that by turning promissory estoppel into a rule of damage limitation, the Texas Supreme Court was attempting to avoid the potential impact of this decision.

159 See text and notes at notes 67-69 \& 143-4 supra; Lost Profits As Contract Damages passim.

160398 S.W.2d at 97 . The court thus transformed what would traditionally be a rule as to the weight of evidence into a rule of exclusion. See also Associated Tabulating Serv. Co. v. Olympic Life Ins. Co., 414 F.2d 1306, 1311-2 (5th Cir. 1969). 
another perspective. In business settings, which normally look to the existence of a contract for the creation of promissory liability, there are only two types of situations where promissory estoppel ever need be invoked. The first is where the parties are so far from reaching a final agreement that it would be implausible to construe their conduct as having matured into a contract. The second is where a situation has become so formalized that it would be stretching construction too far to assert that, in the absence of a specific act, the final prerequisites to contract formation had been satisfied, as where an unconditional offer has been made which the promisee has simply failed to accept prior to revocation. In between these extremes there is an area in which the parties' actions can usually be construed, if the court so desires, as having resulted in the formation of a contract. ${ }^{181}$ In many of these instances it is difficult to explain why a court chooses to proceed on a reliance rather than a contract theory. ${ }^{162}$ But in a case such as Wheeler v. White, where the choice has a substantial impact on the amount of recovery, the most plausible explanation for the choice seems to be the opportunity to limit recovery.

As was the case with Goodman, the result in Wheeler is not particularly distressing, inasmuch as the profits which plaintiff anticipated from the new venture were indeed "speculative." Like Goodman, Wheeler is, at least on its facts, entirely consistent with the proposition that damages for breach of business promise enforced because of actionin-reliance should be the same as damages for breach of contract.

But Wheeler's rationale goes beyond that of Goodman in laying down a rule of damages. In the latter case, it might be hypothesized that the court was responding to the same policies which underlie damage limitation rules in contract actions. In Wheeler, however, the court, by holding that lost profits were unrecoverable regardless of the proof presented, explicitly divorced its result from normal contract damage rules and their policy determinants. In a sense, it divorced the "rule" of Goodman v. Dicker from its underpinnings.

Before commenting on the significance of this fact, it will be helpful to include in the discussion an additional type of decision, in which promissory estoppel may be employed to limit damages other than by way of restricting recovery to out-of-pocket expenditures. The choice between a cause of action based on reliance as opposed to contract may

101 In Associated Tabulating Serv. Co. v. Olympic Life Ins. Co., supra note 160, the negotiations, correspondence, and dealings of the parties, combined with the fact thit plaintiff had commenced work for defendant, might have been construed as having resulted in a contract. It was held that no contract existed but plaintiff was permitted some recovery on a theory of promissory estoppel. Relying on Wheeler $v$. White, recovery of anticipated profits was precluded. Id. at 1311.

162 Henderson at 368-9. 
affect the amount of recovery by triggering the operation of a collateral rule of law which has the effect of barring part of the award. It should be noted that such cases may represent a special instance of that group of decisions where promissory estoppel operates to alter the effects of such legislative rules as the statute of frauds. ${ }^{163}$

The collateral rule involved in Central Heat, Inc. $v$. Daily Olympian, Inc. ${ }^{164}$ was a statute which provided differential time limitations for bringing actions based on written as opposed to oral agreements. The plaintiff was a supplier of heat to three principal customers, among them the defendant. For the season in question, billings were based not upon steam actually used but rather on the average amount of steam taken during the same month of each of the five preceding years, plus a surcharge to cover operating expenses if necessary. Although there was no written agreement signed by both parties, the terms of sale were embodied in the rates and regulations approved by the Central Heat Board of Directors. The defendant, who apparently took little, if any, of the steam for which he was billed, refused to pay. Some three years later the heat company brought suit to recover the amount of the billings. The defendant was found liable on a theory of promissory estoppel. But this did not dispose of the claim, for one of the principal questions was whether part of the claim was barred by the statute which prescribed a three year time limitation for obligations which did not "arise out of any written instrument. . . "The state of the law confronting the court was such that it might reasonably have decided either way. ${ }^{165}$ The statute was held applicable, and most of the claim was barred. The court distinguished cases favoring the application of the six-year statute of limitations for obligations arising out of any written instrument by asserting that in those cases some writing had been delivered to the defendants, while the only record of the terms of sale in the case at bar were contained in the plaintiff's rules and regulations. This neglects the fact that defendant's manager, as well as the managers of plaintiff's other two principal customers, were members of the plaintiff's board of directors at the time the rates were settled upon and had participated in the formulation of the terms of sale. ${ }^{166}$

In view of the fact that the defendant used little steam during the

163 E.g., N. Litterio \& Co. v. Glassman Constr. Co., 319 F.2d 736 (D.C. Cir. 1963); Trinity Universal Ins. Co. v. Ponsford Bros., 414 S.W.2d 16, 29 (Tex. Civ. App. 1967); Associated Tabulating Serv. Co. v. Olympic Life Ins. Co., 414 F.2d 1306, 1311 (5th Cir. 1969); Henderson at $380-3$.

164 74 Wash. 2d 126, 443 P.2d 544 (1968); see also Cooper Petroleum Co. v. LaGloria Oil \&. Gas Co., 436 S.W.2d 889 (Sup. Ct. Tex. 1969), discussed in note 171 infra.

16574 Wash. $2 d$ at 130-3, 443 P.2d at 547-8.

166 Id. at $128,443 \mathrm{P} .2 \mathrm{~d}$ at 546. 
heating season in question, the court's decision to bar most of the claim is reasonable. Nonetheless, it is interesting that they chose to base whatever recovery was allowed on a theory of promissory estoppel rather than contract. Insofar as the court was disposed to grant some recovery, the adoption of a contract theory would have caused some problems with the statute of limitations. Since the defendant had taken no steam, the action could not be sustained on quasi-contractual grounds, subject to the three-year statute of limitations. And while the participation of the defendant's manager in the formulation of the rates and regulations might have permitted the finding of an express, executory contract, the fact that the contract arose out of a "written instrument" would have required the application of a six-year statute of limitations, barring none of the claim. But for the rather convenient result of barring part, but not all of the claim, the use of promissory estoppel seems superfluous.

\section{The Impact of Promissory Estoppel on Traditional Damage Rules}

As interesting as such decisions as Wheeler and Central Heat may be when examined by themselves, their relevance is not confined to the world of promissory estoppel; they also have ramifications germane to the law of contract damages in general. In the first place, there seems to be an increasing habit in the pleading of contract cases of throwing in, for good measure, an alternative count grounded on promissory estoppel. ${ }^{167}$ This practice has occasionally led to appellate confusion as to the appropriate theory of decision. ${ }^{168}$ The most frequent cause of this confusion is the existence of factual elements common to the two promissory causes of action. The facts of a suit brought to enforce a contract often display action taken in reliance on the contract. ${ }^{109}$ While such elements are subsidiary to the enforcement of a normal contract, ${ }^{170}$ they are obviously the prime requisite to enforcement of a promise because of reliance.

But we are concerned with the possibility of studied, rather than inadvertent, confusion. For where a cause of action may be sustained on a theory of promissory estoppel as well as contract, with the former theory precedentially bound to a more limited damage award, the opportunity to manipulate damages is obvious. The instances where the possibility of damage manipulation may arise as it did in Olympic

167 Henderson at 352-3.

$168 \mathrm{Id}$. at $345-50$.

$169 \mathrm{Id}$. at 347. See, e.g., L. Albert \& Son v. Armstrong Rubber Co., 178 F.2d 182 (2d Cir. 1949); City of Memphis v. Ford Motor Co., 304 F.2d 845 (6th Cir. 1962); Security Stove \& Mfg. Co. v. American Ry. Express Co., 227 Mo. App. 175, 51 S.W.2d 572 (1932). See Lost Profits As Contract Damages at 996; see also note 54 supra.

170 Cf. Fuller \& Perdue at 70; Henderson at 347, 368-9. 
Heat probably will not be numerous. Few decisions are likely to present courts with the opportunity to apply a statute of limitations or, for example, the statute of frauds ${ }^{171}$ so as to limit part, but not all, of the award.

If, however, the rule which appears to be emerging from the Goodman and Wheeler decisions becomes more widespread-and this is a likely possibility ${ }^{172}$ - there probably will be a greater temptation to juggle causes of action with an eye to the relevant damage rules. Such a development would not be unique. For example, the practice of treating a breach of contract as tortious conduct for the purpose of permitting recovery of punitive damages has long been recognized.173 The promissory estoppel-contract dichotomy would be, or is, merely another instance of this sort of recharacterization of facts by court or counsel.

But this particular instance is not without its difficulties. Certainly, Wheeler and Goodman must be taken as advancing the proposition that damages for breach of a promise enforced because of reliance are to be measured by the reliance interest exclusive of opportunity costs. However, it must be remembered that they are quite similar-factually if not rhetorically-to numerous decisions in which, on traditional grounds, courts have refused to award damages measured by the expectation interest for breach of contract. ${ }^{174}$ They are therefore consis-

171 One such case may have been Cooper Petroleum Co. v. LaGloria Oil \& Gas Co., 436 S.W.2d 889 (Sup. Ct. Tex. 1969). Fagan, president of a distributing company, was the father-in-law of Clark, who was an officer of and interested in I.M.I., another such company. Plaintiff LaGloria, a supplier of I.M.I. on open account, sought additional guarantees that the accounts would be paid. In mid-December, Clark represented to plaintiff that Fagan would guarantee payment, whereupon plaintiff continued shipping. On about January 4th, Fagan learned that such a promise had been made and did not repudiate the promise until about January 23d. The written guarantee was never supplied. After I.M.I. went bankrupt, plaintiff sued, among others, Fagan on the promised guarantees and recovered in the courts below. The Supreme Court of Texas reversed and remanded for a new trial, holding (I) that contrary to the view of the court of civil appeals the promise to supply a written guarantee was unenforceable because in violation of the statute of frauds; but (2) that Fagan was in any event estopped from denying Clark's apparent authority to make such a promise; and (3) Fagan was liable because LaGloria had acted in reliance on the promise; but (4) liability was limited to the damages incurred between the time when Fagan learned that the promise had been made-January 4 th-and the time when he informed LaGloria that no written guarantee would be executed-January 23d. Thus Fagan was held liable for the price of some of the goods-those shipped between the 4th and 23d of January-but not all of them.

172 Associated Tabulating Serv. Co. v. Olympic Life Ins. Co., 414 F.2d 1306, 1311 (5th Cir. 1969) (approved instruction, which precluded the recovery of lost profits for promissory estoppel, based on Wheeler); cf. L.S. Good \& Co. v. H. Daroff \& Sons, Inc., 279 F. Supp. 925, 927 (N.D. W. Va. 1968).

173 See the instructive remarks of Lord James of Hereford in Addis v. Gramophone Co., [1909] A.C. 488; 5 Corbin $\$ 1077$; see also In re Polemis and Furness, Withy \& Co., [1921] 3 K.B. 560 (Scrutton, L.J.).

174 See text at notes 141-6 and 158-9 supra. 
tent with the proposition that damages for breach of a commercial promise enforced because of reliance should not differ from damages awarded for breach of contract.

But there are decisions such as Quimby in which action-in-reliance is the only available theory of recovery and in which courts have awarded damages measured by the expectation interest by applying traditional contract rules of damages. To the extent that we continue to favor damages measured by the expectation interest for breach of contract, such awards will remain proper. And thus far the Quimby type of decision seems to have maintained its independence of the Goodman-Wheeler position. ${ }^{175}$ If, however, the latter rule becomes generalized, divorced as it was in Wheeler from its roots in traditional contract law, a spillover of the Goodman-Wheeler position into a Quimby type of decision may result in an inappropriate restriction on recovery.

The identical problem will arise in a more general form if the Goodman-Wheeler principle is extended in the opposite direction. Promissory estoppel and the Goodman-Wheeler rule might be invoked in a decision which, like Wheeler, could have been decided on traditional contract grounds but where, unlike Wheeler, traditional rules would have dictated a recovery of the expectation interest. Here, too, the use of the Goodman-Wheeler rule might well result in a limitation on recovery.

Assuming that, but for the limitation of the Goodman-Wheeler rule, the promisees in either of these hypothetical instances would have recovered damages measured by the expectation interest, it will be seen that that rule has the potential for developing into a broad doctrinal device for distributing the promisee's loss between the parties to the action. This development would be at odds with Anglo-American contract law's traditional all-or-nothing approach to damages. Simply stated, we have adhered to the notion that a party in breach will be required to compensate the aggrieved party for losses flowing from the breach. ${ }^{178}$ In many instances that rule has required defendant to bear the burden of losses measured by gains prevented by the breach as well as by tangible expenditures in reliance on the contract. And in such instances the desirability of full compensation of the promisee is buttressed by the deterrent effect which award of the expectation interest is thought to

175 Counsel for the defendant in Quimby argued, on the basis of Goodman, that recovery of lost profits should be disallowed, but this contention was rejected as constituting an "unjustifiable restriction" on the Quimby facts. Chrysler Corp. v. Quimby, 51 Del. 264, 283, 144 A.2d 123, 134 (1958).

1765 CoRbin §§ 992, 1002; Lost Profits As Contract Damages at 992; Stees v. Leonard, 20 Minn. 448, 453-4 (1874); cf. Hawkins v. McGee, 84 N.H. 114, 146 A. 641; Victoria Laundry (Windsor), Ltd. v. Newman Indus., Ltd., [1949] 2 K.B. 528; Fuller \& Perdue at 60. 
provide, encouraging businessmen to honor their promises and promoting security of reliance on business promises.

But these two notions-compensation and, with respect to damages measured by the expectation interest, deterrence-upon which we predicate throwing all the loss on a promisor in breach, are not sufficiently persuasive that this position is the only one that could rationally be adopted. However desirable the goal of full compensation of the promisee, imposing all the loss on the promisor may make promisors in general overly wary of entering into agreements, ${ }^{177}$ particularly if they fear that breach will expose them to liability for substantial lost profits. ${ }^{178}$

It is probably in response to such considerations ${ }^{179}$ that the rule which we state is not the rule which we in fact apply. The common law has developed numerous limitations on plaintiff's recovery for breach of contract. Thus, plaintiff is required to show that his losses are certain in amount, ${ }^{180}$ were foreseeable at the time the contract was consummated, ${ }^{181}$ and were in fact caused by the defendant's breach. ${ }^{182}$ To the extent that plaintiff fails to satisfy these requirements, defendant's liability is reduced. Thus, by denying plaintiff a fully compensatory judgment, the application of these rules has in numerous cases effectively divided the loss between the parties. In view of the foregoing, the approach to damages adopted in Goodman and Wheeler is not of itself offensive to the common law of contract damages. This is particularly so in Goodman and Wheeler themselves where traditional contract damage rules would have rendered an identical result.

But as the Goodman-Wheeler rule becomes divorced from its traditional underpinnings, it may become a blanket prohibition against the recovery of the expectation interest in all promissory estoppel, and certain contract cases, as suggested in the two hypotheticals above. ${ }^{183}$ Thus, on the one hand we are soon likely to find plaintiffs, recovering on a theory of promissory estoppel, denied judgment for lost profits which traditional rules of damages would have permitted. To the extent that this

177 Cf. Fuller \& Perdue at 65.

178 Lost Profits As Contract Damages at 995-6.

179 "It is well settled that the governing purpose of damages is to put the party whose rights have been violated in the same position, so far as money can do so, as if his rights had been observed. . . . This purpose, if relentlessly pursued, would provide him with a complete indemnity for all loss de facto resulting from a particular breach, however improbable, however unpredictable. This, in contract at least, is recognized as too harsh a rule." Victoria Laundry (Windsor), Ltd. v. Newman Indus., Ltd., [1949] 2 K.B. $528,539$.

180 Lost Profits As Contract Damages, text and notes at nn.33-34.

181 E.g., Hadley v. Baxendale, 9 Exch. 341 (1859); Victoria Laundry (Windsor), Ltd. v. Newman Indus., Ltd., [1949] 2 K.B. 528.

182 E.g., Krauss v. Greenbarg, 137 F.2d 596 (3d Cir.), cert. denied, 820 U.S. 791 (1943).

183 Text following note 175 supra. 
occurs there will exist an unwarranted discrepancy between the treatment of contract promisees and promisees who have acted in reliance. On the other hand it may be that, as in the second hypothetical above, promissory estoppel and the Goodman-Wheeler rule will become a vehicle for limiting damages in cases which could have been decided on traditional contract grounds and in which traditional rules of damage would have allowed recovery of the expectation interest. It is possible that the prohibition against recovery of the expectation interest in such cases as Goodman, Wheeler and their progeny is the harbinger of a broader judicial desire to limit recovery of the expectation interest and allocate the promisee's loss between the parties. But here the promissory estoppel-Goodman-Wheeler approach may be criticized as inadequate for the task. Although promissory estoppel may be substituted for contract as the ground for recovery in many instances, ${ }^{184}$ there are numerous cases in which promissory estoppel would simply not be available. Not the least of these instances is the typical bilateral executory business agreement in which breach is likely to occur prior to actionin-reliance. ${ }^{185}$ Accordingly, the impact of the promissory estoppelGoodman-Wheeler approach would simply be the development of a discrepancy within the law of damages between different contract promisees.

In both instances the point seems to be the same. Whether a commercial promisee sues to enforce a contract or a promise upon which he has acted in reliance has no relevance to the question of how much he should recover. The predicates upon which we award the contract promisee the expectation interest dictate a similar recovery by the promisee who has acted in reliance, and we should preclude recovery of such damages by the latter only to the extent that an identical limitation is imposed upon the former. Similarly, whether the facts of a case in which an aggrieved party sues to enforce a contract can incidentally and alternatively be characterized as action-in-reliance is no reason for treating such a party differently, with respect to damages, from a contract promisee whose case cannot be so recharacterized. Once again, those factors which favor or disfavor recovery of damages measured by the expectation interest will operate to the same extent in either case. And insofar as the Goodman-Wheeler rule contains the potential for dictating different results with respect to promisees who on substantive grounds should be accorded similar treatment, that rule may be viewed with disfavor. Certainly the interest of consistent handling of similar cases would suggest the propriety of abandoning the Goodman-Wheeler rule 
and dealing with commercial promisees who have acted in reliance in the same fashion as we now treat normal contract promisees.

This is not to say that contemporary handling of contract damages is fully satisfactory, even with respect to claims for lost profits and the like. Such claims are presently accorded favorable treatment. ${ }^{186}$ This seems correct when viewed in light of our assumptions that the twin goals of compensation and deterrence are not achieved at too great a cost. But it would not require a great shift in thinking to arrive at the contrary conclusion that the costs of inhibiting commercial conduct outweigh the benefits of full compensation. Such a shift would make it theoretically desirable to adopt an approach toward damages which views partial allocation of losses as the preferred remedy in many instances. Indeed, the growing interest in comparative negligence indicates that a similar shift in thinking has recently occurred in the area of tort law. ${ }^{187}$

Moreover, even to the extent to which contract damage law may be said to have developed techniques of damage splitting, the results have not been altogether satisfactory. It is true that the numerous rules which have been developed to limit damages in various instances-by which to divide the risk of loss in such instances-bear silent tribute to the strength of the desire of courts to mitigate the rigors of the common law's all-or-nothing approach to the allocation of loss. But these rules themselves are subject to the criticism that they are sporadic in operation and often are invoked in a fashion which has little or nothing to do with the policy considerations which may underlie the question whether damages should be thrown completely on one party or divided between the parties. ${ }^{188}$ Notwithstanding the inadequacy of these rules, common law courts have been quite reluctant to split damages explicitly ${ }^{189}$ in the absence of specific enabling legislation. ${ }^{190}$ Indeed there

186 Lost Profits As Contract Damages at 1025.

187 See the materials on comparative negligence collected in G.O. GrEGorX \& H. KaLVEN, CASEs \& Materials on Torrs 248-60 (2d ed. 1969).

188 Lost Profits As Contract Damages passim, especially at 1017-24.

189 This aversion to common law damage-splitting is not confined to the law of contract damages. For example, recently an intermediate appellate court adopted a comparative negligence approach in a wrongful death case in the absence of an enabling statute, Maki v. Frelk, 85 Ill. App. 2d 439, 229 N.E.2d 284 (1967), but was reversed on review, Maki v. Frelk, 40 Ill. 2d 193, 239 N.E.2d 445 (1969). Perhaps in response to the numerous problems raised but left unresolved by plaintiff's counsel on oral argument, the latter court took the position that "on the whole the considerations advanced in support of a change in the rule might better be addressed to the legislature." Id. at 197, 239 N.E.2d at 447.

The primary exception to the all-or-nothing common law approach to damages is of course in the area of maritime claims. E.g., The North Star, 106 U.S. 17, 17, 20 (1882); The Margaret, 30 F.2d 923, 928 (3d Cir. 1929); Vassallo v. Nederl-Amerik S.M. Holland, 344 S.W.2d 421 (Sup. C. Tex. 1961). See generally G. Gimmore \& C.L. BLACK, THE LAW of ADMIRALTY 402-4, 434-42 (1957). 
appears to be only one contract case in which an American court has allocated loss between the parties on a percentage basis after breach. ${ }^{191}$ Moreover, that case arose in the United States Court of Claims and in the peculiar context of a contract between the United States government and a private party.

Quite apart from cases involving a distinction between damages measured by the reliance as opposed to the expectation interest, there may also be numerous instances in which a court might have reached a more desirable allocation of loss, or reached it with less straining, were it able to adopt an explicit damage-splitting approach. In some of these cases promissory estoppel has been the technique employed to reach the desired result. Peoples National Bank of Little Rock v. Linebarger Construction Co. ${ }^{192}$ was probably such a case. Plaintiff bank brought an action against a prime contractor for sums which it had advanced to Cart, one of defendant's subcontractors. The subcontract was for the performance of labor, and Cart required interim financing primarily for the purpose of meeting his payrolls. The defendant, unwilling to supply the funds himself, arranged for the necessary financing through the plaintiff bank, which took as security an assignment of the contract installments coming due to Cart. The course of performance between the parties was that defendant would notify the plaintiff monthly by letter of the amount coming due the subcontractor, and plaintiff would advance the whole of that amount to the sub. Events proceeded smoothly until Cart defaulted on his contract; simultaneously, defendant notified the bank that the total amount accruing to Cart under the contract would be $\$ 50,000$ rather than $\$ 60,000$ as originally estimated. At this point the bank was Cart's creditor to the extent of $\$ 16,000$, whereupon it sued defendant to recover this amount.

In a related proceeding, Western Casualty \& Surety Co. v. Linebarger, ${ }^{193}$ Linebarger had sued Cart and the surety on Cart's performance bond for damages for non-completion, the surety having refused to complete the contract. Linebarger recovered a judgment of some $\$ 24,000$ against Cart, who was by then bankrupt; he recovered against the surety for $\$ 16,000$ of this amount.

In the bank's suit against Linebarger, the Supreme Court of Arkansas,

190 With respect to the tort law problem of comparative negligence, many jurisdictions have adopted statutory solutions to the problem. E.g., ARK. STAT. ANN. § 73-1004 (1947); NEB. REv. StAT. \$ 25-1151 (1943); WIs. STAT. § 331.045 (1953); Federal Employers' Liability Act, 35 Stat. 66 (1908), 45 U.S.C. § 53 (1926).

191 National Presto Indus., Inc. v. United States, 338 F.2d 99, 112 (Ct. Cl. 1964).

192219 Ark. 11, 240 S.W.2d 12 (1951). See also Anthony v. Hilo Elec. Light Co., 442 P.2d 64 (Hawaii 1968).

193219 Ark. 48, 239 S.W.2d 753 (1951). It is likely, although it does not appear in either of the opinions which were filed a week apart, that the cases were heard together below. 
observing that the bank had advanced the money to Cart on the strength of defendant's representations of the amount coming due each month, permitted recovery on a theory of promissory estoppel. The opinion limited recovery to approximately $\$ 12,000$, the amount which the bank had proved at trial was actually used to defray Cart's payroll expenses. The court imposed this limitation on two grounds. The first was that the original agreement had been entered into for the purpose of permitting the subcontractor to meet his payrolls between progress payments, and sums not in fact so used were unauthorized by the agreement. The second was that the court felt that awarding damages in excess of this amount would compel defendant to reimburse the bank for loans from which it had received no benefit. ${ }^{194}$

The first argument adduced for limiting recovery was basically a construction of the facts surrounding the agreement. But notwithstanding the reasons which may have originally moved the parties to commence the transaction, the limitation appears arbitrary in terms of the facts of the case. First, the written instrument in no way indicated that it was to be limited to sums advanced to meet payroll expenses and by its terms covered "all sums to be disbursed subsequent to the date of this instrument by the Linebarger Construction Company. ..."'195 More important, the court clearly recognized that the course of performance between the parties was such that defendant "led the bank to believe that checks would be issued in accordance with [defendant's] letters." 196 In each instance, until the installment in controversy, defendant stated that a certain amount would be coming due, plaintiff advanced that amount to Cart, and defendant reimbursed the bank for the whole amount.

The court's second reason resembled a quantum meruit approach to the problem, in that the bank was permitted to recover only those amounts which Cart had in fact used to defray his payrolls and from which Linebarger had presumably derived some benefit. This is a strikingly peculiar reason for the court to have limited recovery. In the first place, it is quite difficult to discern the court's source for this notion. Even more curious is the fact that counsel for the bank has prepared for just such an eventuality, inasmuch as counsel had gone to the trouble of proving at trial not only the amount which the bank had loaned, but also the amount which Gart had used to meet his payrolls. ${ }^{197}$ The only remotely related area of controversy in which such a limitation has arisen involves disputes over priority of assignments

194219 Ark. at 18-20, 240 S.W.2d at 17.

105 Id. at 13 \& $\mathrm{n} .2,240$ S.W.2d at 14.

196 Id. at 18 \& nn.7-8, 240 S.W.2d at 16-17.

197 Id. at 15, 240 S.W.2d at 15. 
under the Assignment of Claims Act between financing banks and sureties on bonds required by the Miller Act in United States government contracts. ${ }^{188}$ In some of these decisions the surety, having failed as an assignee, has attempted to establish priority on a theory of subrogation. Under one of the rationales by which such disputes have been resolved, the surety is allowed to recover only to the extent that the funds loaned by the bank were "diverted" from use on the contract; conversely, the financing bank is entitled to recover or retain progress payments due or paid under the assignment to the extent that the proceeds of its loans were not "diverted." 199 The theory underlying this rule is that the surety on a performance bond has presumably been benefited by loans which were used on the contract since the surety will have to perform that much less work to complete the contract. Consequently, so the theory goes, the bank should be permitted to recover these amounts under its assignment.

Perhaps the court in Linebarger was aware of and drew upon the learning of these decisions. ${ }^{200}$ Indeed, the result in Linebarger with respect to the bank was similar to the results with respect to banks in the bank-surety cases, insofar as the bank was entitled to recover from Linebarger to the extent that the proceeds of the loan were employed to defray Cart's payrolls. Similarly, Linebarger was treated much the same as the surety-subrogee in the surety-bank cases, but only insofar as he was not obligated to the bank for payments from which he had received no benefit.

Yet it remains difficult to see why the notion of diversion, however relevant it may be to the surety-bank conflicts under the Assignment of Claims Act, has anything to do with the decision in Linebarger. In Linebarger the bank did not, as indeed it could not, ${ }^{201}$ recover against defendant as an assignee. It recovered on the independent representation of the amount to be coming due under the contract, a representation upon which the bank had relied to its detriment and to the extent of $\$ 16,000$ not $\$ 12,000$. Not only had defendant made such a representation, but it had also failed to notify the bank promptly when it learned that the estimated contract price was mistakenly high. Had the bank learned of this mistake immediately it might well have declined to advance the $\$ 16,000$ to Cart. Under these circumstances, the arguments

198 See generally 2 Gilmore, Security INTERests in Personal Property ch. 36 (1965).

199 E.g., Coconut Grove Exch. Bank v. New Amsterdam Cas. Co., 149 F.2d 73, 78 (5th Cir. 1945); GILMORE, stupra note 198, § 36.4 n.6.

200 The fact that counsel for the bank went to the trouble of proving how much had not been diverted suggests that they were aware of the doctrine. It is perhaps through their learning that this notion made its way into the Linebarger decision.

201 Text at notes 204-6 infra. 
for awarding the bank the full $\$ 16,000$ appear at least as strong as those for limiting recovery to the amounts actually used to meet Cart's payrolls.

Moreover, even if the bank had recovered as an assignee, the analogy between Linebarger and the surety in the surety-bank cases would have been inapposite. That analogy would have been valid only to the extent that Linebarger bore the burden of Cart's default: in the absence of a surety the prime contractor-obligor in effect performs the role of the surety in completing the contract. ${ }^{202}$ But the effect of the Western Casualty decision was to compel the surety to assume liability on its bonds for the non-completion, ${ }^{203}$ thereby relieving Linebarger of the burden of Cart's default. Accordingly, if anyone was entitled to dispute the bank's recovery of payments accrued under the contract on the ground that the proceeds of the bank's loan had been "diverted" from the contract, it would have been the surety, not Linebarger. Thus the notion of diversion, like the assertion that sums not used to defray payroll expenses were "unauthorized" by the agreement, does not provide a convincing reason for the court's having limited the bank's recovery as a relying promisee.

But there is a completely different way of looking at the problem generated by Linebarger. But for the doctrine of promissory estoppel the bank probably would have recovered nothing. Normally, the financing assignee would be entitled to recover payments earned under the contract prior to default. Although it is not clear whether any of the $\$ 16,000$ which Linebarger had represented as coming due under the contract was in fact earned before Cart's default, it could be presumed that the $\$ 12,000$ which the bank had proved was used to meet Cart's payroll fell into the category of earned payments. Even so, the bank would still have been subject to any claims which Linebarger might have had against Cart.204 Although part of the former's claims against the latter were extinguished by the imposition of liability on Cart's surety, some $\$ 8,000$ of the judgment against Cart was not recovered from the surety. To the extent that the $\$ 8,000$ could not be satisfied against the bankrupt Cart, Linebarger would presumably have been permitted to prove it as a set-off to the bank's recovery as an assignee. Finally, even if payments earned under the contract exceeded Line-

202 Cf. GILMORE, supra note $198, \S 36.8 \mathrm{nn} .4-5$.

203 The damages assessed against Cart were partly for non-completion and partly for corrective work. The surety was held liable for all the damages for non-completion but for only part of the corrective damages. Text and note at note 205 infra.

204 GILMORE, supra note 198, § 41.4; cf. Uniform CoMmercial COdE § 9-318(1)(a) which was not, of course, law at the time of the Linebarger decision but which purports to state the prior law. 
barger's unsatisfied judgment against Gart, those payments would not have been recoverable under the assignment to the extent that they had been allowed as a set-off in determining the damages assessed against Cart and his surety in the Western Casualty case. Because of the obscurity of the Western Casualty opinion, this last question is not easily resolved. The findings of the chancellor are not reproduced in the opinion on appeal. The court states only that a judgment of $\$ 24,000$ was recovered against Cart and that $\$ 16,000$ of this amount was recoverable from the surety. From some additional statements it may be deduced that of the $\$ 24,000$ figure half was probably damages for noncompletion and half damages suffered by virtue of having to repeat work incorrectly done. ${ }^{205}$ It does appear that Cart was allowed some $\$ 9,000$ in credits, ${ }^{206}$ although it does not appear for precisely what these credits were allowed. The most likely possibility is that they were for payment for work completed prior to default but not already paid for. Accordingly, it would appear that as an assignee the bank was entitled to recover nothing from Linebarger. It was probably on this ground that the bank lost in the court below. And by allowing it to recover as a relying promisee the appellate court improved the bank's lot substantially.

But the court must have felt the weight of its dilemma. On the one hand it did allow recovery on a theory of promissory estoppel, and the extent of the bank's reliance was clearly $\$ 16,000$. On the other hand, a financing assignee normally looks to its assignment as security for sums advanced. In this case the bank appears to have taken no steps to protect its security by policing Cart's activities, even though it was undoubtedly encouraged to abdicate this responsibility by the peculiar facts of the case in which Linebarger was the moving party in setting up the financing transaction. Under such circumstances the normal allocation of risk as to the subcontractor's default is imposed on the assignee rather than on the prime contractor. If the court had permitted the bank to recover the full $\$ 16,000$, which was all that Linebarger recovered of a solvent defendant in Western Casualty, the risk of the subcontractor's default as between the bank and the prime contractor would have been completely shifted to the prime contractor. It may be hypothesized that the court in Linebarger recognized that it was working a substantial alteration in the normal allocation of risks, and chose to frame its decision so

205 The court states that the surety was liable for only one-third of the damages assessed for corrective work. 219 Ark. at 49, 239 S.W.2d at 754. Thus, the $\$ 8,000$ of the judgment which was not assessed against the surety must have been two-thirds of the total damages assessed for corrective work, indicating the total of such damages to have been around $\$ 12,000$.

206219 Ark. at 49,239 S.W.2d at 754 . 
as to divide the risk of the subcontractor's default between the assignee and the prime contractor. This result was more equitable than throwing all the loss on the assignee, and less drastic than shifting it completely to the prime contractor. Moreover, it seemed justified by the facts of the case in which both parties were to some degree at fault: the prime contractor for having permitted the bank to act in reliance, and the bank for not having taken steps to protect its security.

In Linebarger, as in Wheeler and Goodman, it appears that the courts were using promissory estoppel as a device by which to divide the losses flowing from a breach between the various parties. The cases are not, however, exact parallels. It has been observed that in Wheeler and Goodman the result achieved with respect to damages might well have been reached on more traditional grounds. ${ }^{207}$ In Linebarger the result appeared to be wholly novel. But, as we have also noted, the GoodmanWheeler rule itself contains the potential for leading to loss allocation in circumstances where traditional rules would have thrown the loss completely on one party or the other. ${ }^{208}$

Moreover, all three cases are similar to the traditional rules which might have been invoked in Wheeler and Goodman, insofar as the method used to reach an allocated solution was somewhat artificial. As loss-splitting devices, the cases, as well as the traditional damage-limitation rules, fail to confront explicitly the questions whether, when, and in what proportion the loss resulting from a breach should be allocated between the parties. ${ }^{209}$

\section{Conclusion}

One is tempted to suppose that there may be numerous decisions, similar to those examined above, where there has been a breach and loss, and in which both parties are to a certain degree responsible for the loss, as was particularly the case in Linebarger. In such cases it might be preferable to our traditional all-or-nothing approach for the court to address the question of responsibility for the loss directly, and to allocate damages on a comparative fault basis similar to that which seems to be developing in the field of tort law. ${ }^{210}$ But such an approach has been adopted in only one American contract decision ${ }^{211}$ and, in the absence of enabling legislation, will probably not be extended beyond the Court of Claims in the near future.

207 See text and notes at notes 141-7 \& 158-60 supra.

208 See text at notes 175 \& $183-5$ supra.

209 See text at notes 185-8 supra.

210 See text and note at note 187 supra.

211 National Presto Indus., Inc. v. United States, 388 F.2d 99 (Ct. Cl. 1964). 
It must be borne in mind, however, that even if the allocation of loss between the parties to an agreement is desirable, the use of promissory estoppel to accomplish this goal may be inappropriate. From an examination of the policy grounds upon which we predicate full compensation of the contractual promisee for his losses, this comment has concluded that the commercial promisee who has acted in reliance should be accorded identical treatment. If we wish to adhere to our traditional approach to contractual damages, that approach should be applied to the relying promisee as well. If the movement towards loss allocation gains pace in the area of promissory liability, it should be implemented in a fashion which treats contractual and relying promisees similarly. To the extent that promissory estoppel becomes particularly identified with more limited damage rules there will exist an unwarranted discrepancy between the treatment of commercial promisees who recover on a theory of contract and those who recover on a theory of action-in-reliance. 